\title{
Size-frequency distribution, growth, and mortality of snow crab (Chionoecetes opilio) and arctic lyre crab (Hyas coarctatus) in the chukchi sea from 2009 to 2013
}

\author{
Jasmin Groß $^{\mathrm{a}, *}$, Brenda Konar ${ }^{\mathrm{a}}$, Thomas Brey ${ }^{\mathrm{b}}$, Jacqueline M. Grebmeier ${ }^{\mathrm{c}}$ \\ a School of Fisheries and Ocean Sciences, University of Alaska Fairbanks, Fairbanks, AK 99775, USA \\ b Alfred-Wegner-Institute, Helmholtz-Centre for Polar and Marine Research, Bremerhaven D-27570, Germany \\ c Chesapeake Biological Laboratory, University of Maryland Center for Environmental Science, Solomons, MD 20688, USA
}

\section{A R T I C L E I N F O}

\section{Keywords:}

Crustacea

Decapoda

Temporal variability

Spatial variability

Latitudinal cline

Benthos

Environmental variables

\begin{abstract}
A B S T R A C T
The snow crab Chionoecetes opilio and Arctic lyre crab Hyas coarctatus are prominent members of the Chukchi Sea epifaunal community. A better understanding of their life history will aid in determining their role in this ecosystem in light of the changing climate and resource development. In this study, the size frequency distribution, growth, and mortality of these two crab species was examined in 2009, 2010, 2012, and 2013 to determine temporal and spatial patterns within the eastern Chukchi Sea, and to identify potential environmental drivers of the observed patterns. Temporally, the mean size of both sexes of $C$. opilio and $H$. coarctatus decreased significantly from 2009 to 2013 , with the number of rare maximum sized organisms decreasing significantly to near absence in the latter two study years. Spatially, the mean size of male and female crabs of both species showed a latitudinal trend, decreasing from south to north in the investigation area. Growth of both sexes of $C$. opilio and $H$. coarctatus was linear over the sampled size range, and mortality was highest in the latter two study years. Life history features of both species related to different environmental parameters in different years, ranging from temperature, the sediment carbon to nitrogen ratio of the organic content, and sediment grain size distribution. Likely explanations for the observed temporal and spatial variability are ontogenetic migrations of mature crabs to warmer areas possibly due to cooler water temperatures in the latter two study years, or interannual fluctuations, which have been reported for $C$. opilio populations in other areas where successful waves of recruitment were estimated to occur in eight year intervals. Further research is suggested to determine if the spatial and temporal patterns found in this study are part of the natural variability in this system or if they are an indication of long-term trends.
\end{abstract}

\section{Introduction}

Crustaceans are one of the most abundant epibenthic organisms in the Chukchi Sea (Bluhm et al., 2009; Feder et al., 2005). As highly mobile organisms, larger crustaceans contribute to the redistribution and remineralisation of organic carbon that falls to the sea floor (Lovrich et al., 1995; Piepenburg et al., 1997). They are one of the main predators in the benthic community, and they also contribute to total benthic energy turnover by providing an important prey base for higher trophic levels such as demersal fish and benthic feeding marine mammals (Frost and Lowry, 1983; Jewett and Feder, 1981).

In the Chukchi Sea, the snow crab Chionoecetes opilio (O. Fabricius, 1788) can be one of the most abundant benthic taxa, with the Arctic lyre crab Hyas coarctatus Leach, 1816 also being fairly abundant (Bluhm et al., 2009; Ravelo et al., 2014). Both species have a boreal-arctic range distribution around North America (Alvsvåg et al., 2009; Bluhm et al., 2009; Bryant, 1991; Comeau et al., 1998; Rand and Logerwell, 2011). They are found over a wide depth range, with $C$. opilio occurring between 30-1400 m water depth at year round bottom water temperatures of -1.5 to $4{ }^{\circ} \mathrm{C}$ (Dawe and Colbourne, 2002), and H. coarctatus occurring between 2 and $457 \mathrm{~m}$ water depth and a similar temperature range as C. opilio (Bryant, 1991). Both species are found on muddy or sandy grounds, and are carnivorous, cannibalistic and opportunistic feeders, preying on gastropods, ophiuroids, crustaceans, bivalves and polychaetes with polychaetes, bivalves and amphipods being the more frequently consumed prey items by C. opilio in the Chukchi Sea (Bryant, 1991; Dawe and Colbourne, 2002; Divine et al., 2015; Ernst et al., 2005; Kolts et al., 2013; Wieczorek and Hooper, 1995a).

\footnotetext{
* Correspondence to: Gänsweide 10, 35745 Herborn, Hessen, Germany.

E-mail address: Jasmin.gross@fulbrightmail.org (J. Groß).
} 
While $H$. coarctatus is not economically important, $C$. opilio is one of the most important commercially fished crab species in the North Atlantic and Pacific (Bailey and Elner, 1989; Lanteigne et al., 1996). Heavy exploitation of male C. opilio occurs in Atlantic Canada, Alaska, and the Sea of Japan. The U.S. fishery is constrained to the eastern Bering Sea (EBS) but it is one of the most valuable crab fisheries in the country with over $\$ 133$ million ex-vessel value (NMFS, 2016; NPFMC, 2010). The EBS fishery is managed as one continuous population with a minimum harvestable size of $78 \mathrm{~mm}$ carapace width (CW) (NPFMC, 2010). All C. opilio fisheries are male-only fisheries to protect the reproductive potential of the stock, with the minimum legal catch limit set to a size that females do not reach (Comeau et al., 1998; SainteMarie and Gilbert, 1998; Sainte-Marie et al., 2008). Chionoecetes opilio fisheries in all regions have exhibited great fluctuations over time due to highly variable recruitment with alternating strong and weak cohorts (Ernst et al., 2012). The observed fluctuations in the $C$. opilio fisheries have caused debates whether this temporal variability is regulated by bottom-up or top-down controls (Émond et al., 2015). It is suggested that bottom-up processes related to climate variability may strongly influence the survival of early benthic life stages, as $C$. opilio is a coldstenothermic species (Dionne et al., 2003; Émond et al., 2015). As a topdown control, predation pressure by Pacific cod, the main vertebrate predator of $C$. opilio in the EBS, can also be a major source of juvenile mortality (Orensanz et al., 2004). However, explanations for this extreme recruitment variability remain not well known (Émond et al., 2015). Along with temporal variability, spatial variability has been observed along a latitudinal cline in the Bering Sea and the Gulf of St. Lawrence, with $C$. opilio size decreasing with increasing latitude (Ernst et al., 2005; Sainte-Marie and Gilbert, 1998). This finding seems to be directly related to lower bottom water temperatures or an environmental covariate (Burmeister and Sainte-Marie, 2010; Somerton, 1981).

Both, $C$. opilio and $H$. coarctatus have a lifecycle that is marked by a pelagic larval phase after hatching, and various juvenile benthic stages. The larvae of $C$. opilio and $H$. coarctatus are pelagic for several months before settling to the seafloor, facilitating potentially long larval dispersal distances, which would allow genetic mixing between distant populations (Bryant, 1991; Puebla et al., 2008). Once the larvae settle to the seafloor, there are three described allometric (defined by CW) and gonad maturity stages (aka, morphology description): (1) immature ( $\leq 34 \mathrm{~mm} \mathrm{CW}$ ), (2) adolescent ( $>34 \mathrm{~mm} \mathrm{CW}$, males with non-differentiated claw, females with narrow abdomen and previtellogenic followed by vitellogenic ovaries), and (3) mature ( $>40 \mathrm{~mm} \mathrm{CW}$, males with differentiated claw, females with broad abdomen) (AlunnoBruscia and Sainte-Marie, 1998; Conan et al., 1992). In all crustaceans, somatic growth is discrete and occurs as a series of moults separated by intermoult periods called instars. The three allometric stages are generated by two critical moults, the puberty moult and the terminal moult. Moult increments decrease in frequency after the puberty moult and moulting occurs at most once a year from instar VI onwards, which is similar for both sexes (Bryant, 1991; Comeau et al., 1998; SainteMarie et al., 1995). However, it was noticed that the size increment and growth pattern of $C$. opilio males and females differ after instar VII (Comeau et al., 1998). The terminal moult is present in both species. Male- and female spawning indices are investigated separately because females mature at a substantially smaller mean size than males, causing variation in male and female spawning biomasses. The size at terminal moult varies for $C$. opilio within and among populations (Bailey and Elner, 1989; Bryant, 1991; Sainte-Marie et al., 1995, 2008).

Estimating the age and growth of crustaceans is extremely difficult because crustaceans periodically cast off their rigid, calcareous exoskeleton, leaving no recognizable aging structures such as growth rings (Hartnoll, 1982; Watson, 1969). Growth is not continuous but discrete and biphasic as it is limited to brief moulting events (Hartnoll, 1982). Thus, the most frequently used measure of growth, CW, is a discontinuous function over time (Brylawski and Miller, 2006; Welch and Epifanio, 1995). There are various means to study crustacean growth but size frequency distributions (SFD) are often used to make inferences about growth, and also age, physiology, survival/mortality, competitive ability, reproductive status, market value of commercial crabs, and population productivity (Bluhm et al., 2009; Brey, 2001; Calder, 1984). However, uncertainty in the estimation of crustacean growth parameters is introduced by the absence of permanent hard exoskeletons, the use of laboratory grown individuals, the margin of error in detecting modes from SFD, and also intrinsic factors such as moult cycles, synchronisation between moulting and reproduction, and size-related growth rates (Company and Sarda, 2000). Nevertheless, somatic growth is one of the most easily measured responses of organisms to environmental conditions because it is influenced by temperature, food availability and quality, water chemistry, biotic factors such as competition or diseases, and environmental stressors such as pollutants (Teissier, 1960). Specifically, temperature and food availability impact growth, and hence body size of invertebrates (MacDonald and Thompson, 1985). For example, SFD of C. opilio in Bonne Bay, Canada have been found to be related to water temperature (Comeau et al., 1998). In the Chukchi Sea, many studies have shown that environmental drivers are important in structuring the epibenthic community abundance and biomass (Bluhm et al., 2009; Feder et al., 2005; Hardy et al., 2011), but only a few have shown how the same drivers may affect the SFD of these organisms (Konar et al., 2014).

To conserve and manage crustaceans in the Chukchi Sea, it is important to understand their size distribution and growth, especially as increasing resource exploitation in the Chukchi Sea and global climate change have raised concerns that the stability of the epibenthic community might be negatively impacted by these acute stressors (Bluhm et al., 2009; Grebmeier, 2012; Piepenburg, 2005). The objectives of this study were to determine the SFD, growth and mortality of both sexes of $C$. opilio and $H$. coarctatus per year and region to determine temporal and spatial trends within the eastern Chukchi Sea, and to identify environmental drivers that explain the observed patterns of these SFD. Three specific hypotheses were formulated based on pre-existing knowledge. As growth and size-at-maturity differ between male and female crabs during later life stages in some areas, it was hypothesized that the size frequency distribution of male and female $C$. opilio snow and $H$. coarctatus would differ significantly from each other in the Chukchi Sea. On the basis of known temporal variation in C. opilio fisheries in the Bering Sea and the Gulf of St. Lawrence, it was also hypothesized that there would be significant interannual variability in the SFD of $C$. opilio and $H$. coarctatus on the Chukchi Sea shelf, and that this variability would be explained by changing environmental parameters, specifically bottom water temperature, and indicators of regional productivity, including sediment total organic carbon content, sediment carbon to nitrogen ratio, and sediment chlorophyll $a$ content.

\section{Materials and methods}

\subsection{Study site}

Crabs and environmental data were collected from 71 stations sampled in the northeastern Chukchi Sea $\left(67^{\circ} \mathrm{N}\right.$ to $72{ }^{\circ} \mathrm{N}, 168^{\circ} \mathrm{W}$ to $157^{\circ} \mathrm{W}$ ) during four summer cruises (July/August in 2009, 2010, 2012 and 2013) as part of the Chukchi Sea Offshore Monitoring In Drilling Area-Chemical And Benthos (COMIDA CAB) project and the Hanna Shoal Ecosystem Study. For this study, size frequency distributions (SFD) were determined for $C$. opilio and $H$. coarctatus from 32 and 18 stations, respectively, over the 4 cruises (Fig. 1). Stations where less than 20 crabs were sampled were left out of the analysis. In 2012, C. opilio and in 2013, $H$. coarctatus, were not abundant enough at any stations so these years were left out of the analysis of the respective species. Sites used in these analyses ranged in water depth from $28 \mathrm{~m}$ to $65 \mathrm{~m}$. The 2009 and 2010 cruises covered a broad spatial area, while the 2012 and 2013 cruises focused on the northeastern Chukchi Sea 


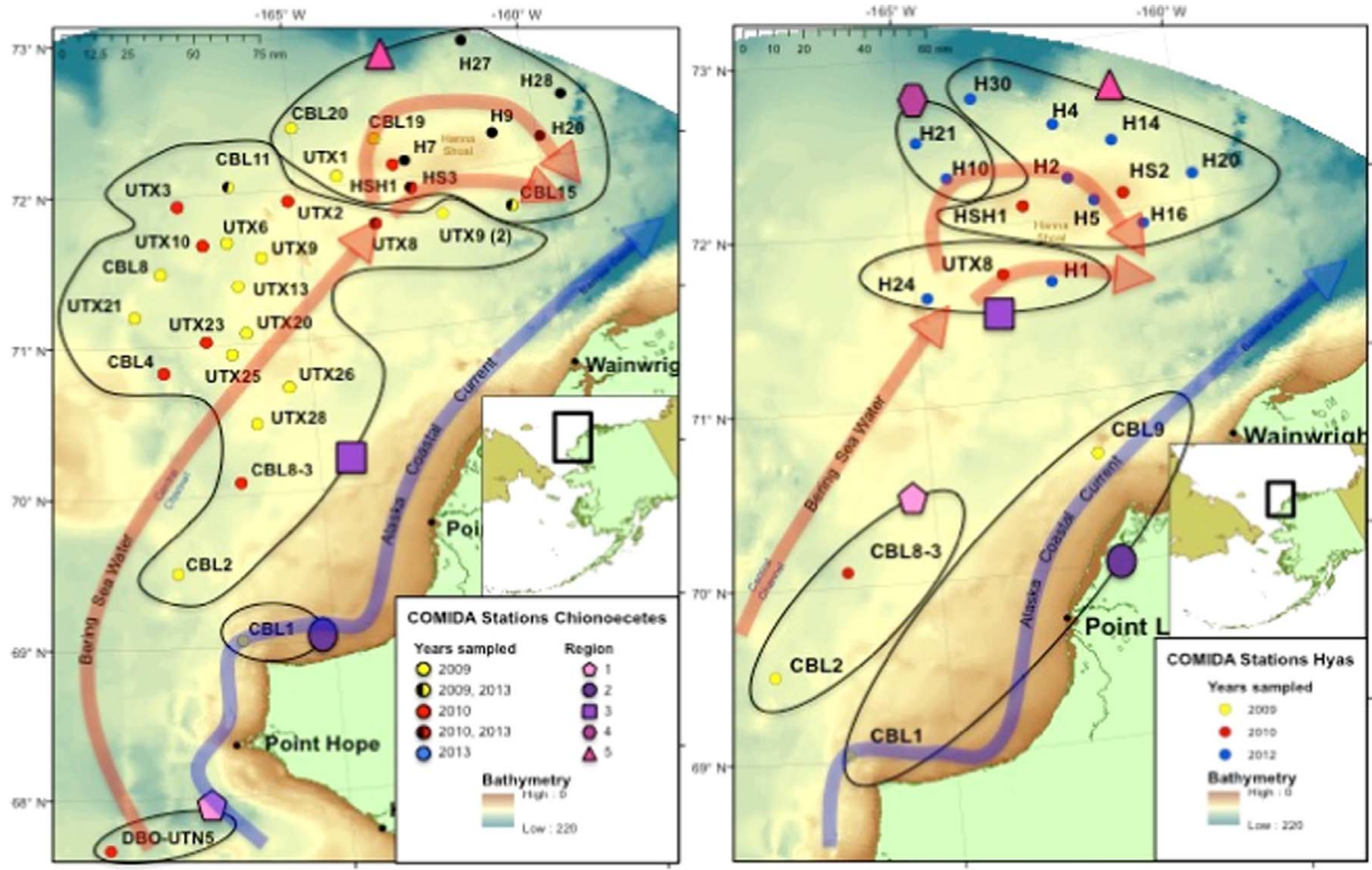

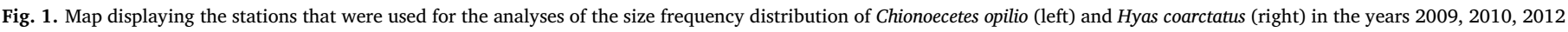
and 2013. Stations allocated to a specific region are encircled with a black line, and the attached symbol indicates the region number.

around Hanna Shoal (Fig. 1). Two methods were used for the selection of sampling sites to ensure that sites were randomly distributed. The first sites were chosen with a general randomised tessellation stratified design (GRTS) in GIS, while the other sites were spatially oriented, nearshore to offshore, on a south to north grid that overlaid the GRTS design. For the spatial analysis, stations were grouped into regions based on the prevailing currents in the sampling area (Fig. 1). Two major currents influence the northeastern Chukchi Sea: the Alaska Coastal Current (ACC) and the Bering Sea Water (BSW) (Weingartner et al., 2005, 2013). The ACC flows northward along the coast of Alaska and is characterised by warm, low salinity water with a low nutrient content (Weingartner et al., 2005; Fig. 1). The BSW flows through the Central Channel and is characterised by cold, high salinity water with a high nutrient content (Weingartner et al., 2005; Fig. 1). It continues to Hanna Shoal in a slow flow, displaces the cold, saline winter waters that form during the ice-covered season and merges with the ACC close to Barrow Canyon (Weingartner et al., 2005, 2013). Region 1 is the most southern region, influenced by BSW that comes through the Bering Strait. Region 2 includes the coastal stations, influenced by the ACC (Fig. 1). Regions 3 and 4 include the furthest offshore stations influenced by the BSW that flows through the Central Channel and along the western side of Hanna Shoal. Region 3 also includes stations influenced by the slow flowing BSW south of Hanna Shoal. Region 5 is the most northern region, influenced by BSW flowing around northern Hanna Shoal (Fig. 1).

\subsection{Sampling technique}

\subsubsection{Epibenthic sampling}

The epibenthos was sampled with a $3.05 \mathrm{~m}$ plumb-staff beam trawl with a $7 \mathrm{~mm}$ mesh and a $4 \mathrm{~mm}$ codend liner, which was modified with lead-filled line and $15 \mathrm{~cm}$ sections of chain seized to the footrope every $15 \mathrm{~cm}$. The net was deployed at an average vessel speed of 1.5 knots, with an average bottom time of 2.5 minutes depending on the relative epibenthic density, which was determined by a drop video camera (LW Cooper, personal communication). The mouth of the net was held open with a rigid $3 \mathrm{~m}$ pipe allowing an effective swath of $2.26 \mathrm{~m}$. The vertical net opening was $1.2 \mathrm{~m}$ wide and catch weight ranged between 40 and $100 \mathrm{~kg}$, which was determined using a digital hanging scale with a 0.01 accuracy. It has to be noted that early settlement cohorts are probably not adequately represented using this mesh size because small individuals $(<7 \mathrm{~mm})$ are excluded from sampling with the occasional exception of smaller individuals found in the mud that accumulated in the net.

Each trawl catch was sieved over $4 \mathrm{~mm}$ mesh to remove sediments. Crabs were sorted by species and sex and then counted, weighed, and carapace size was measured to the nearest millimetre using calipers. In 2009 and 2010, the carapace length was measured and converted to carapace width. In 2012, carapace length and width were measured to establish a conversion factor between carapace length and width. In 2013, only carapace width was measured to ensure standardization with literature data where carapace width is commonly reported (Jadamec et al., 1999). For each data point, carapace width was divided by the corresponding carapace length. The average of all data points was used as the conversion factor as there was no significant difference in conversion factor between the different size classes, which was determined through a regression analysis (Groß, 2015).

\subsubsection{Environmental analysis}

Parameters that have been reported as influential to the epibenthic community structure in the Chukchi Sea (Ravelo et al., 2014) were measured at each station and in each year. Water temperature $\left({ }^{\circ} \mathrm{C}\right), \mathrm{pH}$, salinity, and dissolved oxygen $\left(\mathrm{mg} \mathrm{L}^{-1}\right)$ were measured as a continuous vertical profile using a YSI Sonde 6600V2-4 (Yellow Springs, Ohio, USA) but only bottom water parameters were used in the analysis. A $0.1 \mathrm{~m}^{2}$ van Veen grab was used to collect surface sediment to determine total organic carbon (TOC, \%), total organic nitrogen (TON, \%), the carbon to nitrogen $(\mathrm{C} / \mathrm{N})$ ratio, sediment chlorophyll $a$ (sediment chl a, $\mathrm{mg} \mathrm{m}^{-2}$ ), and sediment grain size (\% phi size) (Dunton et al., 2015). 


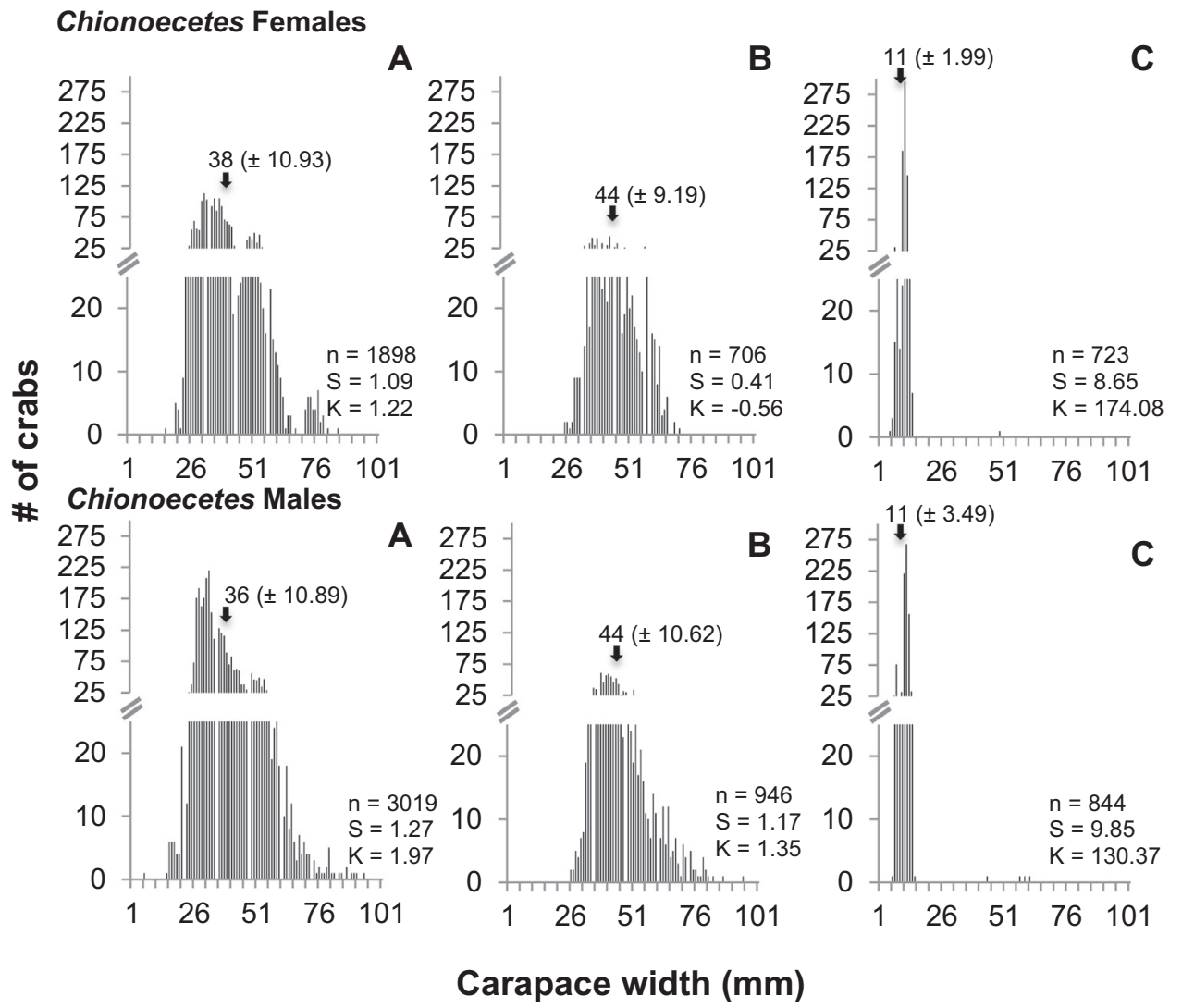

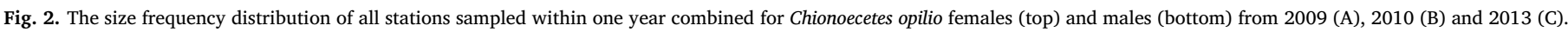
Arrows indicate the mean with the standard deviation in brackets. $\mathrm{n}=$ sample size, $\mathrm{S}=$ Skewness, $\mathrm{K}=$ Kurtosis.

\subsection{Data analysis}

The size frequency distributions (SFD) were generated in Excel by station and region. The regional SFD were standardized to relative proportions because of unequal station numbers among regions. The size frequency data for both species were square root transformed to normalise the spread of the data around its mean for multivariate analysis. To determine differences among years, region, and between sex, a three-factor mixed model permutational analysis of variance (PERMANOVA) was run in PRIMER v.6 package based on a Bray Curtis resemblance matrix. Year, region and sex were treated as fixed factors. A pairwise comparison of means was calculated at a 0.05 significance level for all years and regions. Differences of maximum sizes among years of males and females of both species were determined by comparing the average size of the highest percentile (10\% largest individuals) with a one-way analysis of variance (ANOVA) in R. A Tukey's HSD post hoc test was performed in $\mathrm{R}$ for significant results of the one-way ANOVA at a 0.05 significance level.

The environmental data collected in all four years were normalized and a Euclidean distance resemblance matrix was created. Based on this matrix, the Distance Based Linear Model (DistLM) routine in PRIMER was used to establish which environmental variables best correlated with the SFD of both species. Latitude $\left({ }^{\circ} \mathrm{W}\right)$, longitude $\left({ }^{\circ} \mathrm{N}\right)$ and depth (m) were used as indirect determinants, while sediment chl a, TOC, $\mathrm{TON}$, and the $\mathrm{C} / \mathrm{N}$ ratio were used as indicators of regional productivity. Also included in the analysis were salinity, temperature, dissolved oxygen, $\mathrm{pH}$, and sediment grain size. Correlating environmental variables (conductivity, oxygen saturation) were excluded from the analysis based on a Draftsman's plot, and when necessary, variables were log or square root transformed.

Size-at-age data (SAD), adapted from Comeau et al. (1998) for $C$. opilio in Bonne Bay, Canada at temperatures ranging from $-1^{\circ}$ to $1^{\circ} \mathrm{C}$, were used to determine a growth function as it was not possible to determine age from the data sampled in this study. SAD for $H$. coarctatus were also adapted from Comeau et al. (1998), as there is no published SAD for $H$. coarctatus covering the same size range that was recorded in this study. Growth of males and females of both species was linear for the size range recorded in this study, which is not necessarily true for sizes beyond the sampled range. The data were fitted with adequate precision to a linear growth model using the equation: $S_{t}=a+b \times t$, where $\mathrm{S}_{\mathrm{t}}$ is the size at time $\mathrm{t}$, a is the intercept of the linear growth function, $b$ is the slope of the linear growth function, and $t$ is time (Bryant, 1991; Comeau et al., 1998). An analysis of covariance (ANCOVA) was performed in $\mathrm{R}$ to determine if growth differed significantly between males and females of both species. Sex was treated as the categorical variable, age as the covariate, and size as the dependent variable. The type III sum of squares was calculated, as the design was unbalanced. The analysis was run with and without the interaction term, and an ANOVA was used to compare which statistical design was more appropriate. Mortality was determined using a numbers versus age curve, where the basic model consists of a plot of the natural logarithm of the number of crabs caught in various age groups against their corresponding age groups. The natural logarithm of the frequency of all data points of the descending right arm of the numbers versus age curve was calculated. The natural logarithm of the frequency of all data points was plotted against age, and a linear trendline was fitted to the scatter for 2009, 2010 and 2013 for C. opilio, and 2009, 2010 and 2012 for $H$. coarctatus. The following equation was used to determine mortality from the resulting linear equation of the trendline: $Z=-b$, where $\mathrm{Z}$ is the instantaneous total mortality coefficient, which in this case is equal to natural mortality as $C$. opilio and $H$. coarctatus are not commercially fished in the Chukchi Sea, and b is the slope of the linear trendline. An ANCOVA was also performed for this model, with year as the categorical variable, age as the covariate and 


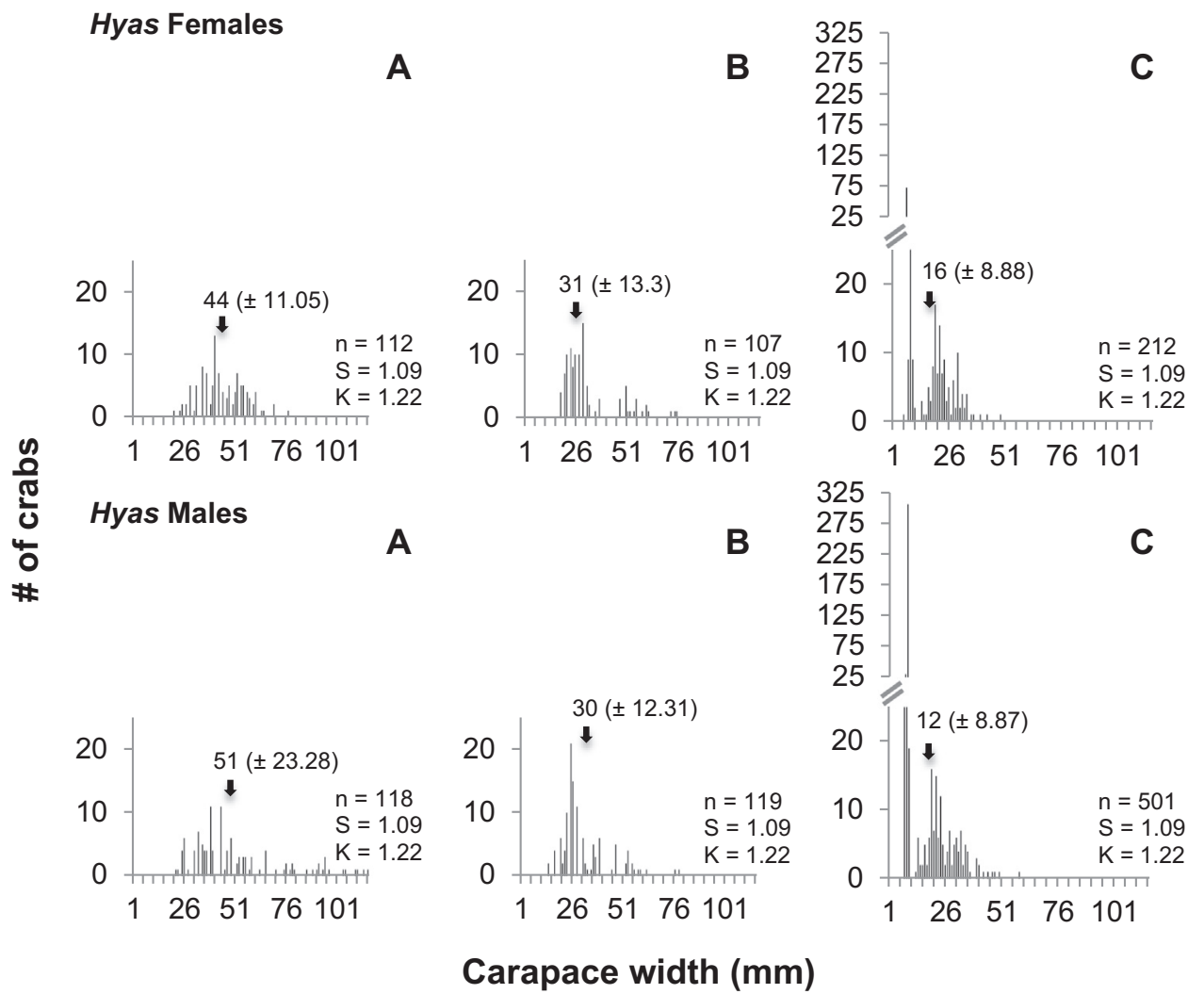

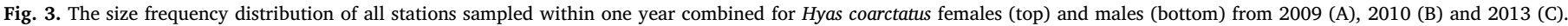
Arrows indicate the mean with the standard deviation in brackets. $\mathrm{n}=$ sample size, $\mathrm{S}=$ Skewness, $\mathrm{K}=$ Kurtosis.

the natural logarithm of frequency as the dependent variable. The type III sum of squares was calculated here as well, because the design was unbalanced. The analysis was also run with and without the interaction term, and an ANOVA was used to determine which design was more appropriate.

\section{Results}

The snow crab $C$. opilio was found at more sampling stations and was more abundant in all sampling years than the Arctic lyre crab $H$. coarctatus (Figs. 1, 2 and 3). Female crabs of both species were consistently less abundant than male crabs, with the male crabs also reaching larger maximum sizes than the females (Figs. 2 and 3). However, female crabs had equal or larger mean sizes than males in all years with the exception that for $H$. coarctatus, females had a smaller mean size ( $44 \pm 11 \mathrm{~mm})$ than males in 2009 (51 $\pm 23 \mathrm{~mm}$; Figs. 2 and 3). The largest $C$. opilio male was $94 \mathrm{~mm}$ while the largest female was $84 \mathrm{~mm}$. The largest $H$. coarctatus male was $115 \mathrm{~mm}$ while the largest female was $76 \mathrm{~mm}$ (Figs. 2 and 3). These maximum sized specimens were all caught in the first sampling year (2009), except the male $C$. opilio, which was caught in 2010 (Figs. 2 A, B and 3A). The decrease in maximum size over the sampling period was not gradual for both sexes of $C$. opilio, as the average size of the highest percentile increased from $60 \mathrm{~mm}$ in 2009 to $67 \mathrm{~mm}$ and $61 \mathrm{~mm}$ in 2010 for males and females, respectively. It then dropped to $14 \mathrm{~mm}$ and $13 \mathrm{~mm}$ in 2013 for males and females, respectively (Table 1 ). The average maximum size of the highest percentile of both sexes of $H$. coarctatus decreased from $101 \mathrm{~mm}$ and $64 \mathrm{~mm}$ in 2009 to $33 \mathrm{~mm}$ and $32 \mathrm{~mm}$ in 2012 for males and females, respectively (Table 1). The average maximum size of the highest percentile of male and female crabs of both species differed significantly among years (ANOVA, $C$. opilio male: $F_{2}=1276.3$, $p<0.001$; $C$. opilio female: $F_{2}=1618.9, p<0.001 ; H$. coarctatus male: $F_{2}=456.49, p<0.001 ; H$. coarctatus female: $\left.F_{2}=137.77, p<0.001\right)$. A
Table 1

The average maximum size (Max) of the highest percentile (10\% largest individuals), sample number (n) and standard deviation (SD) for males and females of both sexes.

\begin{tabular}{|c|c|c|c|c|c|c|c|c|c|c|c|c|}
\hline \multirow[b]{3}{*}{ Year } & \multicolumn{6}{|c|}{ Chionoecetes opilio } & \multicolumn{6}{|c|}{ Hyas coarctatus } \\
\hline & \multicolumn{3}{|c|}{ Female } & \multicolumn{3}{|c|}{ Male } & \multicolumn{3}{|c|}{ Female } & \multicolumn{3}{|c|}{ Male } \\
\hline & $\mathbf{n}$ & Max & SD & $\mathbf{n}$ & $\operatorname{Max}$ & SD & $\mathbf{n}$ & $\operatorname{Max}$ & SD & $\mathbf{n}$ & $\operatorname{Max}$ & SD \\
\hline 2009 & 190 & 60 & 7.82 & 302 & 60 & 7.84 & 11 & 64 & 5.54 & 12 & 101 & 8.7 \\
\hline 2010 & 71 & 61 & 2.51 & 95 & 67 & 6.7 & 11 & 61 & 8.05 & 12 & 58 & 8.76 \\
\hline 2012 & - & - & - & - & - & - & 21 & 32 & 4.77 & 50 & 33 & 6.29 \\
\hline 2013 & 72 & 13 & 4.24 & 84 & 14 & 9.09 & - & - & - & - & - & - \\
\hline
\end{tabular}

pairwise comparison showed that the maximum size of both species of male crabs differed significantly among all years, but that for females, C. opilio were only significantly different between 2009 and 2013, and 2010 and 2013, and H. coarctatus between 2009 and 2012, and 2010 and 2012 (Tukey's HSD, $p<0.05$; Table 2). The SFD of male and female $H$. coarctatus differed significantly (PERMANOVA, Pseudo- $F_{1}=4.35$,

Table 2

Tukey's HSD results comparing the average maximum size of the highest percentile for both species, Chionoecetes opilio and Hyas coarctatus, among all possible pairs of the factor year, showing the p-values with a significance level of $\alpha=0.05$ (* denotes significant results). The dash (-) indicates that values were not calculated.

\begin{tabular}{llllll}
\hline & \multicolumn{2}{l}{ Chionoecetes opilio } & & \multicolumn{2}{l}{ Hyas coarctatus } \\
\cline { 2 - 3 } \cline { 5 - 6 } Year & Female & Male & & Female & Male \\
\hline 2009,2010 & 0.5379 & $<0.0001^{*}$ & & 0.5115 & $<0.0001^{*}$ \\
2009,2012 & - & - & $<0.0001^{*}$ & $<0.0001^{*}$ \\
2009,2013 & $<0.0001^{*}$ & $<0.0001^{*}$ & & - \\
2010,2012 & - & - & $<0.0001^{*}$ & $<$ \\
2010,2013 & $<0.0001^{*}$ & $<0.0001^{*}$ & & - & $-0001^{*}$ \\
\hline
\end{tabular}


Table 3

PERMANOVA results for the SFD of both species, Chionoecetes opilio and Hyas coarctatus, showing the Pseudo-F statistic with corresponding degrees of freedom (df) and p-values with a significance level of $\alpha=0.05$ (* denotes significant results).

\begin{tabular}{llllllll}
\hline & \multicolumn{3}{l}{ Chionoecetes opilio } & & \multicolumn{2}{l}{ Hyas coarctatus } \\
\cline { 2 - 3 } \cline { 7 - 8 } Factor & Pseudo-F & df & p-value & & Pseudo-F & df & p-value \\
\hline Year & 38.689 & 2 & $0.0001^{*}$ & & 4.0384 & 2 & $0.0007^{*}$ \\
Region & 2.6466 & 3 & $0.0029^{*}$ & & 1.7409 & 4 & $0.0262^{*}$ \\
Sex & 1.2909 & 1 & 0.2202 & & 4.3516 & 1 & $0.0001^{*}$ \\
Year $\times$ Region & 1.4196 & 2 & 0.12 & & 1.532 & 1 & 0.16 \\
Year $\times$ Sex & 1.6352 & 2 & $0.0485^{*}$ & & 1.763 & 2 & $0.0549^{*}$ \\
Region $\times$ Sex & 1.1931 & 3 & 0.2378 & & 0.7318 & 4 & 0.8346 \\
Year $\times$ Region $\times$ Sex & 1.2583 & 2 & 0.1946 & & 0.29412 & 1 & 0.9617 \\
\hline
\end{tabular}

Table 4

Pairwise comparison of the factors that showed a significant result in the PERMANOVA for both species Chionoecetes opilio and Hyas coarctatus. Displayed are the t-statistic with the corresponding degrees of freedom (df) and the p-values with a significance level of $\alpha=0.05$ (* denotes significant results). The dash (-) indicates that values were not calculated.

\begin{tabular}{|c|c|c|c|c|c|c|c|}
\hline \multirow[b]{2}{*}{ Comparison } & \multirow[b]{2}{*}{ Group } & \multicolumn{3}{|c|}{ Chionoecetes opilio } & \multicolumn{3}{|c|}{ Hyas coarctatus } \\
\hline & & t-value & df & p-value & t-value & df & p-value \\
\hline \multirow[t]{5}{*}{ Year } & $\begin{array}{l}2009 \\
2010\end{array}$ & 2.8549 & 42 & $0.0001 *$ & 0.85991 & 4 & 0.6173 \\
\hline & $\begin{array}{l}2009 \\
2012\end{array}$ & - & - & - & & & \\
\hline & $\begin{array}{l}2009 \\
2013\end{array}$ & 7.9224 & 42 & $0.0001 *$ & - & - & - \\
\hline & $\begin{array}{l}2010 \\
2012\end{array}$ & - & - & - & 2.7664 & 18 & $0.0003^{*}$ \\
\hline & $\begin{array}{l}2010 \\
2013\end{array}$ & 7.4696 & 28 & $0.0001 *$ & - & - & - \\
\hline \multirow[t]{10}{*}{ Region } & 1,2 & - & - & - & 0.77396 & 2 & 0.7043 \\
\hline & 1,3 & 0.86559 & 36 & 0.5772 & 1.1976 & 2 & 0.3005 \\
\hline & 1,4 & - & - & - & & & \\
\hline & 1,5 & 1.4836 & 20 & $0.0363^{*}$ & 1.3033 & 14 & 0.1295 \\
\hline & 2,3 & 1.6872 & 36 & $0.033^{*}$ & & & \\
\hline & 2,4 & - & - & - & & & \\
\hline & 2,5 & 2.5044 & 20 & $0.0008^{*}$ & & & \\
\hline & 3,4 & - & - & - & 1.6822 & 4 & 0.087 \\
\hline & 3,5 & 1.8022 & 56 & $0.0023^{*}$ & 1.2598 & 16 & 0.1441 \\
\hline & 4,5 & - & - & - & 1.3803 & 16 & 1.3803 \\
\hline \multirow{4}{*}{$\begin{array}{c}\text { Year } \times \text { Sex } \\
\text { Female, } \\
\text { Male }\end{array}$} & 2009 & 1.4382 & 28 & 0.0816 & 1.3727 & 2 & 0.2185 \\
\hline & 2010 & 1.4777 & 14 & $0.0321^{*}$ & 1.8262 & 2 & 0.0883 \\
\hline & 2012 & - & - & - & 1.7416 & 16 & $0.0098^{*}$ \\
\hline & 2013 & 1.257 & 14 & 0.1986 & - & - & - \\
\hline
\end{tabular}

$p=0.0001$ ), in contrast to male and female $C$. opilio, which did not differ significantly in their SFD (PERMANOVA, Pseudo $F_{1}=1.29$, $p=0.2202$; Table 3 ). The interaction term between year and sex was significant for $C$. opilio but not for $H$. coarctatus (PERMANOVA, C. opilio: Pseudo- $F_{2}=1.64, \quad p=0.0485 ; \quad H$. coarctatus: $\quad$ Pseudo- $F_{2}=1.76$, $p=0.0549$; Table 3). A pairwise comparison showed that the interaction between year and sex was significant for $C$. opilio in 2010 while it was significant for $H$. coarctatus in 2012. This means that the hypothesis that the size frequency distribution of male and female $C$. opilio and $H$. coarctatus would differ significantly from each other in the Chukchi Sea was not fully supported as they did not differ significantly from one another in each year sampled (Pairwise comparison, $p<0.05$; Table 4).

\subsection{Temporal comparison}

A decrease in mean size was observed for both species throughout the sampling time. Mean size of female $C$. opilio decreased from 38 $( \pm 11) \mathrm{mm}$ in 2009 to $11( \pm 2) \mathrm{mm}$ in 2013 , and males decreased from 36 ( \pm 11$) \mathrm{mm}$ in 2009 to 11 ( \pm 4 ) $\mathrm{mm}$ in 2013 (Fig. 3) with a total absence of sizes above $48 \mathrm{~mm}$ for females and $60 \mathrm{~mm}$ for males (Fig. 2). The standard deviation in 2013 was much smaller than in 2009 and 2010 (Fig. 2). The mean size of $H$. coarctatus females decreased from $44( \pm 11) \mathrm{mm}$ in 2009 to $16( \pm 9) \mathrm{mm}$ in 2012 , while males decreased from $51( \pm 23) \mathrm{mm}$ in 2009 to $12( \pm 9) \mathrm{mm}$ in 2012 (Fig. 3). The SFD of both males and females were widely spread around the mean in 2009 and 2010, while the standard deviation was lower in 2012 (Fig. 3). The hypothesis that there would be significant interannual variability in the SFD of $C$. opilio and $H$. coarctatus was only partially supported by the data. The difference in size was significant among years for both species (PERMANOVA, C. opilio: Pseudo$F_{2}=38.69, p=0.0001 ; H$. coarctatus: Pseudo- $F_{2}=4.04, p=0.0007 ;$ Table 3) but a pairwise comparison showed that $C$. opilio differed significantly in size among all years while $H$. coarctatus only differed significantly in size between 2010 and 2012 (Pairwise comparison, $p<0.05$; Table 4). The SFD of both species were asymmetrically distributed and right skewed. The SFD of the males of both species were more highly skewed than females. This could be caused by a difference in molting patterns as females are assumed to molt once a year after instar VII until they reach the terminal molt around instar XI while the male growth pattern seems to be density-dependent between instar X and XII causing either (1) a terminal molt, (2) a molt which allows males to stay juvenile and retain the possibility of further growth, or (3) skip molting which inhibits growth (Comeau et al., 1998; Figs. 2 and 3). Skewedness was most pronounced for male and female C. opilio in 2013 (females: 8.65, males: 9.85), while skewedness for $H$. coarctatus males was most pronounced in 2012 (1.84) and for females in 2010 (1.57). Kurtosis was mostly positive with exceptions for the SFD of female C. opilio in $2010(-0.56)$ and female $H$. coarctatus in 2009 $(-0.24)$ and $2012(-0.32)$. Kurtosis for the SFD of males of both species was more positive than the SFD of the females (Figs. 2 and 3).

\subsection{Spatial comparison}

To observe spatial trends, the SFD data of all stations across years were combined by region. The mean size of $C$. opilio females showed a clear trend of decreasing mean size from south (region 1) to north (region 5). The same decreasing trend was observed for the mode of each region, with regions 3 and 5 having equal modes (Fig. 4). This decreasing trend was not as pronounced for $C$. opilio males, as a peak in mean size was present in region 2 , which was closest to the coast. The mode of each region of $C$. opilio males showed the same pattern as the mean (Fig. 4). The SFD differed significantly among regions (PERMANOVA, Pseudo- $F_{3}=2.65, p=0.0029$; Table 3 ). A pairwise comparison showed that region 2 , in the southern part of the sampling area, differed significantly from regions 3 and 5 , which are both located further north. Region 5, which is furthest north, also differed significantly from regions 3 and 1 , indicating that there was a difference between northern and southern stations that might not have been represented by means alone (Table 4).

The mean size of $H$. coarctatus was smaller in northern regions compared to the south; however, this trend was not as pronounced as for C. opilio females. Both mean and mode showed a peak in region 2, which was also observed for $C$. opilio males (Fig. 4). The mean and mode were smallest in region 4 , which was furthest offshore. This could indicate that male and female $H$. coarctatus decrease in size with increasing distance from coast. Patterns for the mean and mode were similar for both males and females; however, the mode of both sexes was equal in regions 3, 4 and 5, while the mean varied among those northern regions (Fig. 4). The SFD differed significantly among regions (PERMANOVA, Pseudo- $F_{4}=1.74, p=0.0262$; Table 3 ), but a pairwise comparison did not reveal which regions differed significantly among each other as sample sizes were too small to establish a test statistic (Table 4). 


\section{Chionoecetes opilio}
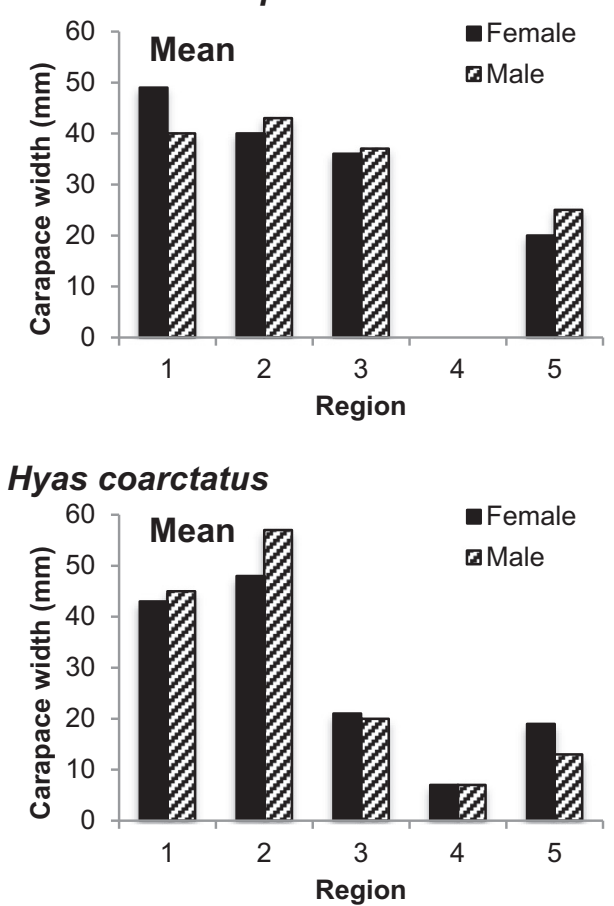

A

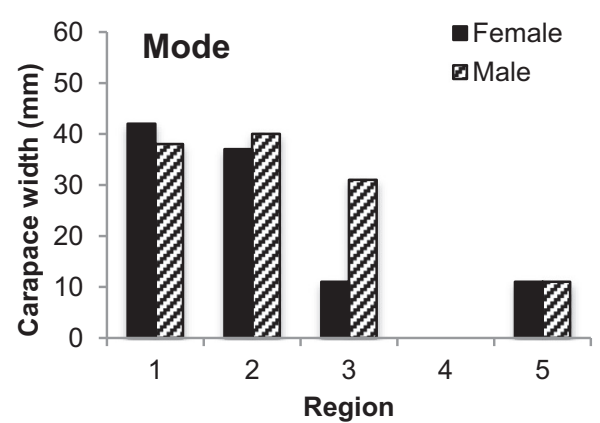

C

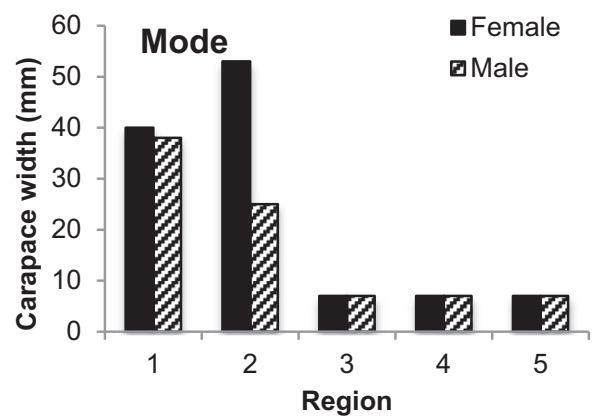

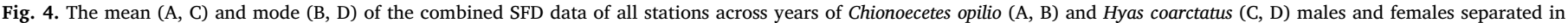
regions as shown in Fig. 1.

\subsection{Environmental analysis}

The environmental variables that best explained the variation in the SFD data matrixes varied between species, sexes, and among years. While none of the tested environmental variables significantly explained the variation in the SFD of C. opilio females in 2009, three explained the variation for $C$. opilio males in 2009. Overall, the sediment $\mathrm{C} / \mathrm{N}$ ratio, bottom water temperature, and salinity explained $43.67 \%$ of variability in the data matrix, with the sediment $\mathrm{C} / \mathrm{N}$ ratio accounting for $15.7 \%$ of the variability (Table 5). In 2010, two environmental parameters significantly explained the variation in the SFD of $C$. opilio females, while none of the measured environmental parameters were significant in explaining the variation for $C$. opilio males. Longitude and sediment grain size $<0 \varphi$ explained $60.24 \%$ of the variability in the data matrix of $C$. opilio females, with longitude accounting for $40.55 \%$ of the explained variability (Table 5). In 2013, three environmental variables significantly explained the variation in the SFD of $C$. opilio females, while only one explained the variation in $C$. opilio males. Sediment modal size, sediment grain size $2 \varphi$, and salinity explained $53.95 \%$ of the variability in the SFD data matrix of $C$. opilio females while sediment $\mathrm{C} / \mathrm{N}$ ratio explained $33.35 \%$ of the variability for the males (Table 5).

Fewer environmental parameters explained the variation in the SFD of $H$. coarctatus, which may be because the number of stations per year was smaller than for C. opilio. In 2009 , depth explained $61.61 \%$ and $71.84 \%$ of the variability in the SFD matrix of $H$. coarctatus males and females, respectively, but neither was significant (Table 6). In 2010, no variable significantly explained the variation in the SFD for males but temperature explained $48.12 \%$ of the variability for females (Table 6 ). In 2012, one environmental variable significantly explained the variation for females while two did for males. The dissolved oxygen concentration explained $34.83 \%$ of the variability for females while sediment grain size $>5 \varphi$ and sediment grain size $<0 \varphi$ explained $45.6 \%$ of the variability for males (Table 6 ).

Table 5

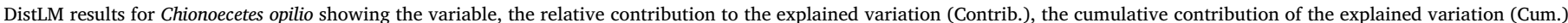
and p-values with a significance level of $\alpha=0.05$ (* denotes significant results).

\begin{tabular}{|c|c|c|c|c|c|c|c|c|c|}
\hline \multirow[b]{2}{*}{ Sex } & \multirow[b]{2}{*}{ Number of Variables } & \multicolumn{4}{|l|}{ Chionoecetes opilio female } & \multicolumn{4}{|l|}{ Chionoecetes opilio male } \\
\hline & & Variable & Contrib. (\%) & Cum. (\%) & p- value & Variable & Contrib. (\%) & Cum. (\%) & p-value \\
\hline \multirow[t]{4}{*}{2009} & 1. & Longitude $\left({ }^{\circ} \mathrm{W}\right)$ & 13.71 & 13.71 & 0.0656 & $\mathrm{C} / \mathrm{N}(\%)$ & 15.7 & 15.7 & $0.0146^{*}$ \\
\hline & 2. & Temperature $\left({ }^{\circ} \mathrm{C}\right)$ & 10.42 & 24.13 & 0.1347 & Temperature $\left({ }^{\circ} \mathrm{C}\right)$ & 12.11 & 27.81 & $0.0329 *$ \\
\hline & 3. & Sediment Grain Size $2 \phi$ & 8.92 & 33.05 & 0.1906 & Salinity & 15.86 & 43.67 & $0.0011^{*}$ \\
\hline & 4. & Latitude $\left({ }^{\circ} \mathrm{N}\right)$ & 8.8 & 41.85 & 0.1444 & Latitude $\left({ }^{\circ} \mathrm{N}\right)$ & 6.19 & 49.86 & 0.1457 \\
\hline \multirow[t]{3}{*}{2010} & 1. & Longitude $\left({ }^{\circ} \mathrm{W}\right)$ & 40.55 & 40.55 & $0.0007^{*}$ & TOC (\%) & 14.36 & 14.36 & 0.1972 \\
\hline & 2. & Sediment Grain Size $<0 \phi$ & 19.69 & 60.24 & $0.0021 *$ & TON (\%) & 17.15 & 31.51 & 0.1157 \\
\hline & 3. & TOC (\%) & 9.89 & 70.13 & 0.0751 & Mean Sediment Grain Size 1-4 $\phi$ & 16.1 & 47.61 & 0.1093 \\
\hline \multirow[t]{5}{*}{2013} & 1. & Temperature $\left({ }^{\circ} \mathrm{C}\right)$ & 30.5 & 30.5 & 0.1119 & $\mathrm{C} / \mathrm{N}(\%)$ & 33.35 & 33.35 & $0.0375^{*}$ \\
\hline & 2. & Sediment Modal Size & 31.61 & 62.11 & $0.0146^{*}$ & Sediment Grain Size $3 \phi$ & 16.6 & 49.95 & 0.0776 \\
\hline & 3. & Sediment Grain Size $2 \phi$ & 12.45 & 74.56 & $0.0484 *$ & Depth (m) & 15.53 & 65.47 & 0.0969 \\
\hline & 4. & Salinity & 9.89 & 84.45 & $0.0372 *$ & Temperature $\left({ }^{\circ} \mathrm{C}\right)$ & 13.35 & 78.82 & 0.107 \\
\hline & 5. & Sediment Grain Size $4 \phi$ & 5.78 & 90.24 & 0.2537 & Mean Sediment Chlorophyll $a$ & 7.63 & 86.44 & 0.1941 \\
\hline
\end{tabular}


Table 6

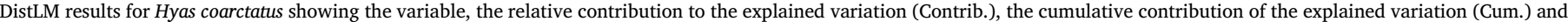
p-values with a significance level of $\alpha=0.05$ (* denotes significant results).

\begin{tabular}{|c|c|c|c|c|c|c|c|c|c|}
\hline \multirow[b]{2}{*}{ Sex } & \multirow[b]{2}{*}{ Number of variables } & \multicolumn{4}{|l|}{ Hyas coarctatus female } & \multicolumn{4}{|l|}{ Hyas coarctatus male } \\
\hline & & Variable & Contrib. (\%) & Cum. (\%) & p-value & Variable & Contrib. (\%) & Cum. (\%) & p- value \\
\hline 2009 & 1. & Depth (m) & 71.84 & 71.84 & 0.1708 & Depth (m) & 61.61 & 61.61 & 0.1679 \\
\hline \multirow[t]{2}{*}{2010} & 1. & Temperature $\left({ }^{\circ} \mathrm{C}\right)$ & 48.12 & 48.12 & $0.046^{*}$ & Temperature $\left({ }^{\circ} \mathrm{C}\right)$ & 49.57 & 49.57 & 0.1283 \\
\hline & 2. & Salinity & 29.77 & 77.88 & 0.3716 & Dissolved Oxygen Concentration & 31.2 & 80.77 & 0.3019 \\
\hline \multirow[t]{3}{*}{2012} & 1. & Dissolved Oxygen Concentration & 34.83 & 34.83 & $0.0025^{*}$ & Sediment Grain Size $>5 \phi$ & 31.52 & 31.52 & $0.0021 *$ \\
\hline & 2. & Sediment Grain Size $<0 \phi$ & 13.22 & 48.05 & 0.0695 & Sediment Grain Size $<0 \phi$ & 14.09 & 45.6 & $0.0527^{*}$ \\
\hline & 3. & Specific Conductivity $(\mathrm{mS} / \mathrm{cm})$ & 12.23 & 60.27 & 0.0813 & Sediment Modal Size & 10.75 & 56.35 & 0.1317 \\
\hline
\end{tabular}

These results indicate that some variation in SFD of Chukchi Sea crabs was explained by changing environmental parameters, in particular bottom water temperature, sediment TOC, sediment $\mathrm{C} / \mathrm{N}$ ratio, and chlorophyll $a$ content in the sediment. Of these, the latter three can be used as proxies for regional productivity. In some years, the variation in the SFD of both species was not significantly explained by any of the tested environmental parameters. Sediment TOC and chlorophyll $a$ did not explain any of the variation in the SFD for either species in any year (Tables 5 and 6). The variation in the SFD of female C. opilio and male $H$. coarctatus was not explained by temperature or sediment $\mathrm{C} / \mathrm{N}$ ratio but the variation in the SFD of male $C$. opilio was significantly explained by temperature and sediment $\mathrm{C} / \mathrm{N}$ ratio in 2009 , and only by the sediment $\mathrm{C} / \mathrm{N}$ ratio in 2013 , and the variation in the SFD of female $H$. coarctatus was significantly explained by bottom water temperature in 2012 (Tables 5 and 6).

\subsection{Growth and mortality models}

Individual growth of both species could be approximated by linear models in the size range sampled in this study. Female crabs of both species grew slower than males, as the slope and the intercept of the linear growth model of the females were significantly smaller than the slope and the intercept of the males (ANCOVA, C. opilio: $F_{1}=18.68$, $p<0.001 ; H$. coarctatus: $F_{1}=63.852, p<0.001$; Fig. 5 , Table 7). The
Table 7

ANCOVA results for the growth model of Chionoecetes opilio and Hyas coarctatus, with sex as the categorical factor, age as the covariate and size as the dependent variable. Displayed are the test statistic (F-value), the degrees of freedom (df) and the significance value (p-value) at a 0.05 significance level (* denotes significant results).

\begin{tabular}{llllllll}
\hline & \multicolumn{3}{l}{ Chionoecetes opilio } & & \multicolumn{2}{l}{ Hyas coarctatus } \\
\cline { 2 - 4 } \cline { 6 - 8 } Variable & F-value & df & p-value & & F-value & df & p-value \\
\hline Age & 4316.482 & 1 & $2.2 \mathrm{e}-16^{*}$ & & 3391.585 & 1 & $2.2 \mathrm{e}-16^{*}$ \\
Sex & 27.547 & 1 & $4.376 \mathrm{e}-07^{*}$ & 52.348 & 1 & $1.130 \mathrm{e}-11^{*}$ \\
Age: Sex & 18.68 & 1 & $2.582 \mathrm{e}-05^{*}$ & 63.852 & 1 & $1.289 \mathrm{e}-13^{*}$ \\
\hline
\end{tabular}

negative intercept of the trendline showed that the growth of both sexes of both species was not linear in the first year, as they did not fall on the linear trendline fitted to the data (Fig. 5). Mortality of both sexes of $C$. opilio and $H$. coarctatus females was lowest in 2010, while it was lowest for $H$. coarctatus males in 2009 (Fig. 6). The highest mortality of both sexes for both crabs was observed in the latter two sampling years (Fig. 6). The rise in mortality in the latter two study years was, however, only significant for $C$. opilio females and $H$. coarctatus males (ANCOVA, C. opilio: $F_{1}=60.4835, p<0.001 ; H$. coarctatus: $F_{1}=9.4802$, $p=0.008795$; Table 8). For $C$. opilio males and $H$. coarctatus females, the ANOVA showed that the ANCOVA design without the interaction was more parsimonious (Table 8). Mortality of $H$. coarctatus males increased

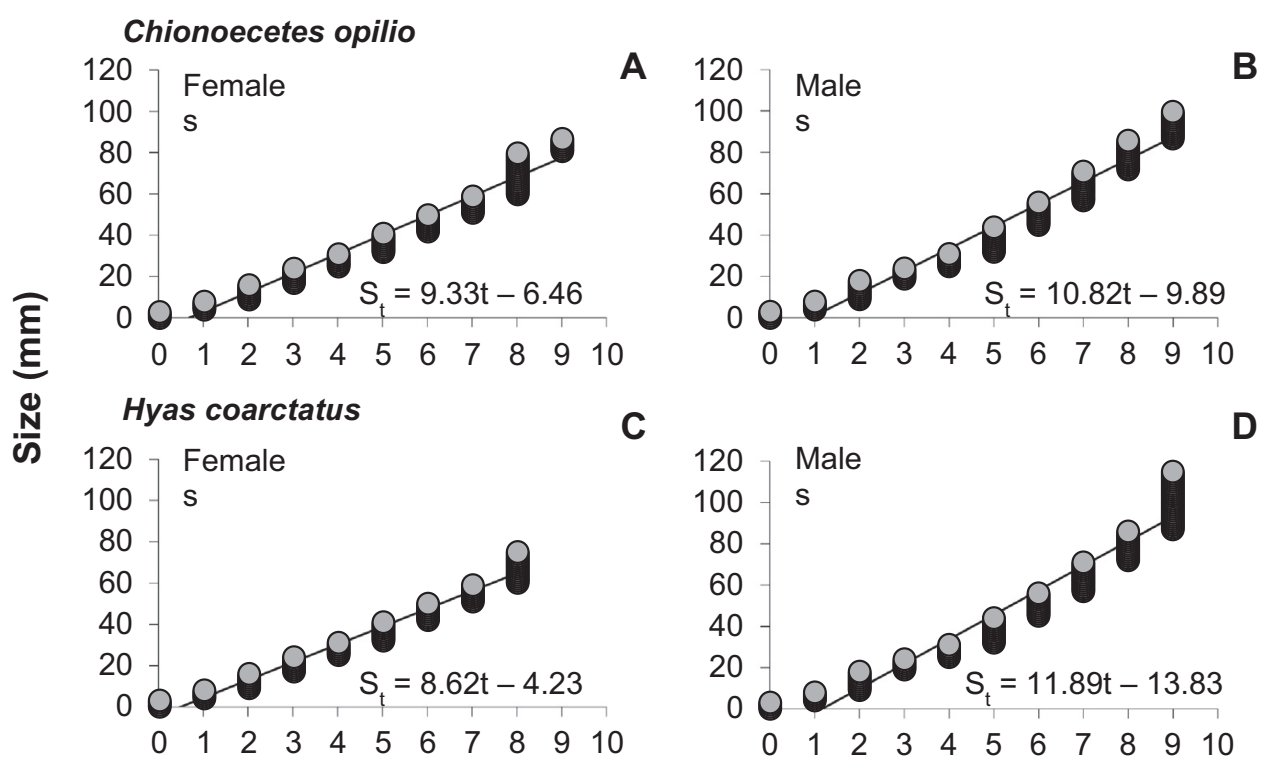

Age (year)

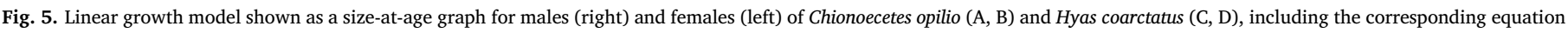

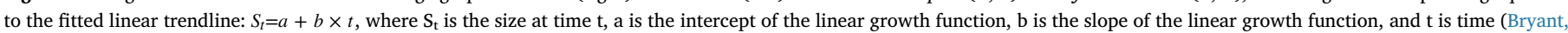
1991; Comeau et al., 1998). Size-at-age data were adapted from Comeau et al. (1998). 


\section{Chionoecetes opilio}
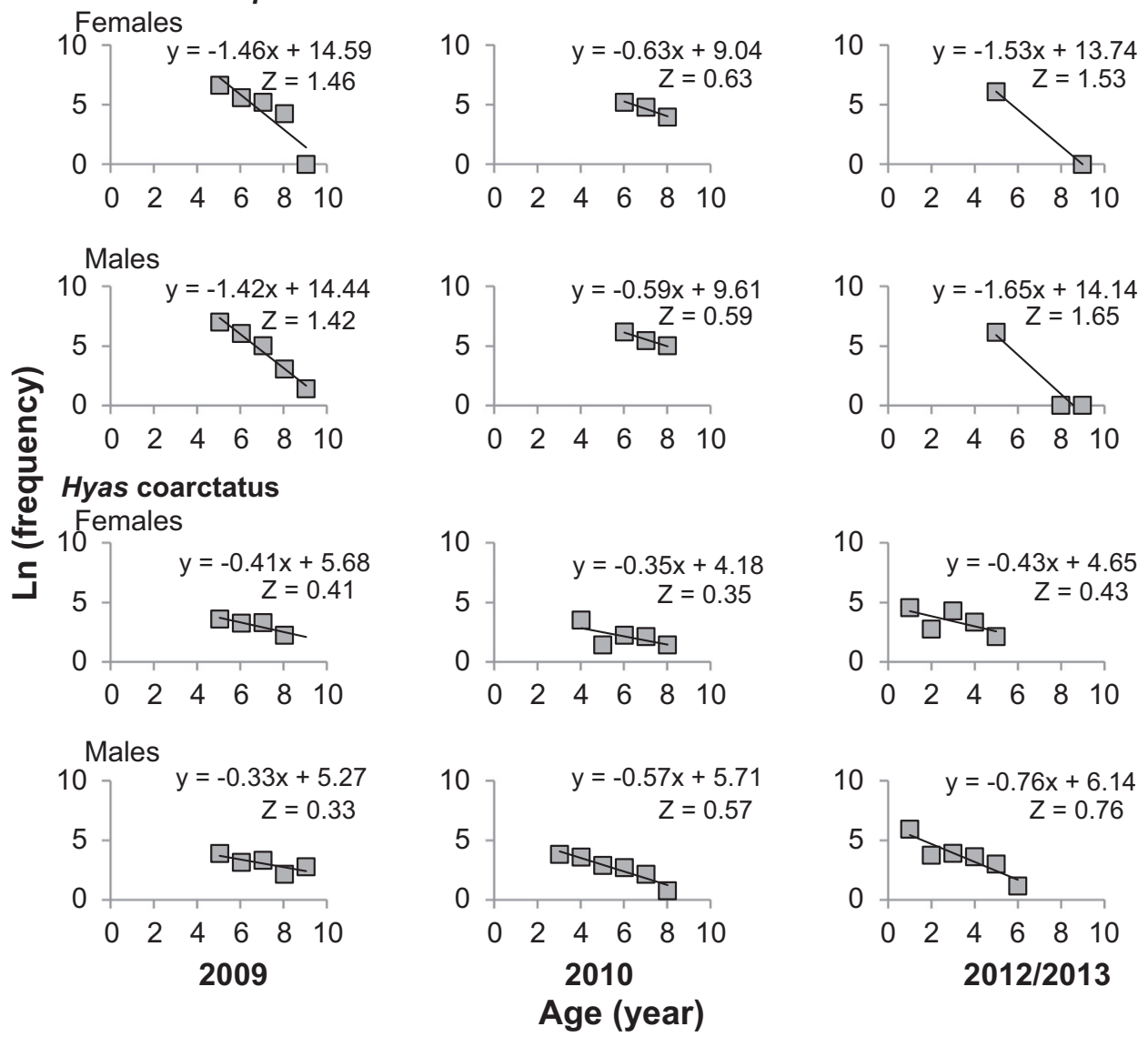

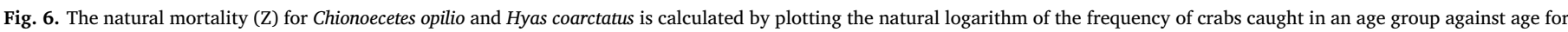

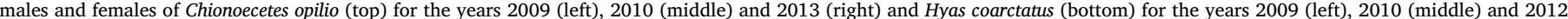
(right). Graphs include the corresponding equation to the fitted linear trendline and the natural mortality factor (Z).

gradually from 2009 to 2012. Overall, C. opilio had greater mortality coefficients than $H$. coarctatus (Fig. 6). Mortality of both sexes of both crabs increased with rising age. It was fairly constant over the entire size spectrum sampled in this study for both sexes of $C$. opilio, except in 2009, where a sudden rise in mortality of the females was observed between age eight and age nine (Fig. 6). Mortality of both sexes of $H$. coarctatus was less constant across all sizes in this study than that of $C$. opilio, as outliers were present in all sampling years. This discontinuity in mortality was more pronounced for $H$. coarctatus females than males, and outliers varied among age groups (Fig. 6).

\section{Discussion}

This paper presents one of the first temporal records of size frequency distributions (SFD) of Chionoecetes opilio and Hyas coarctatus in the Chukchi Sea for several years in a row. The first hypothesis, that the size frequency distribution of male and female $C$. opilio and $H$. coarctatus would differ significantly from each other was not fully supported as $C$. opilio females only differed significantly from males in 2010, and the two sexes of $H$. coarctatus only differed significantly from each other in 2012. As in previous studies, however, male crabs obtained larger maximum sizes than females for both species (Alvsvåg et al., 2009; Bryant, 1991). The largest C. opilio female was larger $(84 \mathrm{~mm})$ than the largest published size for $C$. opilio females $(63$ $\mathrm{mm}$ ) in the Chukchi Sea (Jewett and Feder, 1981). The largest male in this study $(94 \mathrm{~mm})$ was larger than the largest male found in the literature $(75 \mathrm{~mm})$ in the Chukchi Sea (Frost and Lowry, 1983). The majority of $C$. opilio from this study were sub-legal size for the eastern Bering Sea $C$. opilio fishery, which has a legal catch size of individuals larger than $78 \mathrm{~mm}$ (NPFMC, 2010). Most large C. opilio in the northeastern Chukchi Sea are between 35 to $70 \mathrm{~mm}$ in carapace width, which is below the legal catch size (Bluhm et al., 2009; Frost and Lowry, 1983;

Table 8

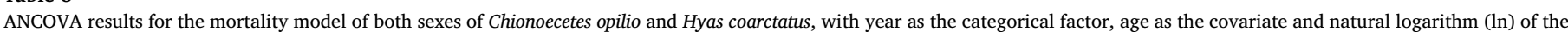

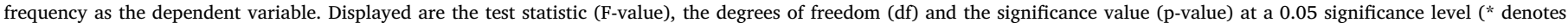
significant results). The dash (-) indicates that models without the interaction term were more appropriate than the ones with the interaction term.

\begin{tabular}{|c|c|c|c|c|c|c|c|c|c|c|c|c|}
\hline \multirow[b]{3}{*}{ Variable } & \multicolumn{6}{|c|}{ Chionoecetes opilio } & \multicolumn{6}{|c|}{ Hyas coarctatus } \\
\hline & \multicolumn{3}{|l|}{ Female } & \multicolumn{3}{|l|}{ Male } & \multicolumn{3}{|l|}{ Female } & \multicolumn{3}{|l|}{ Male } \\
\hline & F-value & df & p-value & F-value & df & p-value & F-value & df & p-value & F-value & df & p-value \\
\hline Age & 21.1503 & 1 & $0.0024873^{*}$ & 9.1327 & 1 & $0.0116134 *$ & 9.2252 & 1 & $0.0113^{*}$ & 46.4701 & 1 & $1.23 \mathrm{e}-05^{*}$ \\
\hline Year & 0.8611 & 1 & 0.3843079 & 28.4171 & 1 & $0.0002408^{*}$ & 2.063 & 1 & 0.1787 & 9.2285 & 1 & $0.009520^{*}$ \\
\hline Age: Year & 60.4835 & 1 & $0.0001091 *$ & - & - & - & - & - & - & 9.4802 & 1 & $0.008795^{*}$ \\
\hline
\end{tabular}


Goodman et al., 2012; Jewett and Feder, 1981). A recent study found $C$. opilio individuals up to $119 \mathrm{~mm}$ in the Beaufort Sea (Rand and Logerwell 2011). Larger maximum sizes in other areas demonstrate that $C$. opilio may be experiencing reduced growth in the Chukchi Sea. Historic carapace width data for $H$. coarctatus do not exist for the Chukchi Sea but the maximum carapace length was reported at $7.3-7.5 \mathrm{~cm}$ for males and $4.6-4.9 \mathrm{~cm}$ for females (Frost and Lowry, 1983; MacGinitie, 1955). However, reported carapace width ranges around the Isle of Man, Scotland (20-29 mm and 17-28 mm for males and females, respectively) (Bryant, 1991) are smaller than those found in this study $(12-51 \mathrm{~mm}$ and $16-44 \mathrm{~mm}$ for males and females, respectively).

\subsection{Temporal comparisons}

Two clear temporal trends were observed in the SFD of $C$. opilio and $H$. coarctatus. The mean size and the rare maximum sized individuals of both sexes decreased from 2009 to 2013. The decline in mean size of $C$. opilio was not gradual (Figs. 2 and 3). The data only partially support the second hypothesis, that there is significant interannual variability in the SFD of $C$. opilio and $H$. coarctatus. The SFD of $C$. opilio differed significantly between all years while the SFD of $H$. coarctatus only differed significantly between 2010 and 2012. This suggests that the SFD of $C$. opilio started changing earlier than the SFD of $H$. coarctatus. However, speculations about temporal trends made in this study are questionable due to the limited number of repeat stations and the limited (four years) temporal spread of the data.

There are many possibilities as to why mean carapace width decreased during the study period and why mature crabs $(>40 \mathrm{~mm})$ of both species were nearly absent in 2012 and 2013 while immature crabs $(<34 \mathrm{~mm})$ were fairly abundant in these two years. One possibility could be ontogenetic migrations of larger crabs to areas with warmer bottom water temperatures as colder temperatures were observed around Hanna Shoal in the latter two study years compared to previous years (Groß, 2015). The occurrence of colder bottom water temperatures around Hanna Shoal could be caused by a shift in the local current regime. Bering Sea water usually replaces the cold, dense winter water that forms on Hanna Shoal in the early summer but slower flushing times could result in the colder bottom water temperatures observed in 2012 and 2013 (Day et al., 2013; Weingartner et al., 2005). The reduced productivity of brachyuran crabs in sub-zero temperatures may be causing ontogenetic migrations to deeper waters (Ernst et al., 2005; Orensanz et al., 2007; Sainte-Marie and Gilbert, 1998). Sub-zero temperatures limit or even inhibit crab growth and lead to smaller sizeat-maturity (Ernst et al., 2005; Kolts et al., 2015). Ontogenetic migration of adult $C$. opilio females out of extremely cold temperatures results in increased reproductive potential because size-at-maturity is limited at cold temperatures and this decreases their reproductive potential. Clutch size is reduced in smaller females and egg developmental rate is slowed down in colder temperatures, resulting in a two year incubation at temperatures below $2{ }^{\circ} \mathrm{C}$ (Burmeister, 2002; Comeau et al., 1999; Kolts et al., 2015). The relation between body and clutch size has been noted for numerous brachyuran crabs including $H$. coarctatus females (Bryant, 1991; Hines, 1982). Female body size is important in determining population growth, through fecundity and reproductive output, which may be why mature females actively seek out habitats with warmer temperatures (Bryant, 1991; Conan et al., 1996). The scarcity of mature female crabs in a given area is an indication that ontogenetic migration may even begin before maturity is reached, leading to spatial segregation of mature and immature crabs (Comeau et al., 1998).

One other possibility for the almost exclusive presence of juveniles in the later study years may be that these are less mobile than mature crabs and most likely limited to the area of settlement. However, it is not well known if initial recruitment to an area depends on larval settlement or post-settlement dispersal of instars I to III $(0 \sim 8 \mathrm{~mm})$
(Kolts et al., 2013), as only immature crabs of instar IV ( $>9 \mathrm{~mm}$ ) were consistently found in this and one other study (Kolts et al., 2015). One indication that larval settlement determines higher juvenile crab abundance is the slowing of water around Hanna Shoal, which favors larval settlement (Kolts et al., 2015; Weingartner et al., 2005). Larval settlement conditions were also more favorable around Hanna Shoal due to shallow waters with coarse grain sediment and cold bottom water temperatures. Predation and cannibalism are assumed to be reduced in those habitats making them favorable for more frequently molting immature crabs (Bryant, 1991; Comeau et al., 1998; Kolts et al., 2015; Lovrich et al., 1995). Large crabs can exclude small crabs from the same habitat due to cannibalism; hence cannibalism on immature crabs was most likely reduced in 2012 and 2013, as large crabs were nearly absent during that time. Predation may also have been reduced around Hanna Shoal as only 16-91 fish $1000 \mathrm{~m}^{-2}$ were found in the pool of cold winter water south of Hanna Shoal, whereas 207 fish $1000 \mathrm{~m}^{-2}$ were found in warmer regions in the northeastern Chukchi Sea in 2009 and 2010 (Day et al. 2013). This finding could explain why cold temperatures reduce predation on small crabs, and why small crabs were present in high numbers in 2012 and 2013. The scarcity of mature crabs and the high numbers of immature crabs on Hanna Shoal in 2012 and 2013 also suggests that the population is being sustained from elsewhere, and that larvae advected from one area are deposited in another. This is not uncommon for brachyuran crabs as female breeding habitats are often disjunct from nursery grounds (Parada et al., 2010). It seems that immature and mature crabs not only have different habitat preferences, in terms of depth and sediment grain size, but that the distribution of crabs is also influenced by habitat suitability, current flow and their migration behaviour.

Cannibalism of larger crabs on smaller crabs led to habitat segregation in Bonne Bay and the Gulf of St. Lawrence, Canada (Comeau et al., 1998; Wieczorek and Hooper, 1995b). Immature C. opilio inhabited shallower waters with coarser, gravelly sediment and mature crabs inhabited deeper waters with finer, muddy sediment. The coarser, gravelly sediment provides refuge from predators and higher food abundance (Comeau et al., 1998; Lovrich et al., 1995; Robichaud et al., 1989). Observed differences in the feeding behaviour and diet of small and large crabs could also lead to habitat segregation, and explain the near absence of mature crabs in 2012 and 2013, as immature and mature crabs have been found in different benthic communities in other areas (Lefebvre and Brêthes, 1991). Overall prey abundance, regardless of prey taxa, can determine the distribution of crabs as feeding is largely opportunistic (Kolts et al., 2013). It could be that the overall decline in the prey base, reported as a drop in abundance and biomass of the epifauna in 2012 and 2013, caused a decline in the abundance of mature C. opilio and H. coarctatus in the same years (Kolts et al., 2013; Powell, this issue). Mature crabs of both species preferably feed on other, larger epibenthic organisms while immature crabs feed on amphipods and small bivalves with soft shells (Kolts et al., 2013). There is an indication that the benthic macrofauna in the northeastern Chukchi Sea has been persistent over four decades. Small bivalves, like Macoma calcarea and Ennucula tenuis were listed as dominant in the benthic macrofaunal biomass while amphipods dominated by abundance, possibly allowing higher abundances of immature crabs around Hanna Shoal (Grebmeier et al., 2015b). It is also known that compared to other regions in the Alaskan Arctic, C. opilio in the southern and northern Chukchi Sea had a relatively high frequency of occurrence of brachyuran crabs, possibly juvenile $C$. opilio, in their diet composition (Divine et al., 2015). Habitat segregation in the Chukchi Sea on the basis of food availability and feeding behavior is therefore likely but further studies like diet composition of immature C. opilio $(\leq 34 \mathrm{~mm}$ CW) in the Chukchi Sea are necessary to draw this conclusion.

\subsection{Spatial comparisons}

The one clear spatial trend that was observed in the size frequency 
distribution (SFD) of both crab species was that mean size decreased from south to north. This trend was more pronounced for $C$. opilio than $H$. coarctatus, and it was most prominent for $C$. opilio females. This result confirms previous findings of a spatial north-south trend in the SFD of both species in the Chukchi Sea (Burmeister and Sainte-Marie, 2010; Jewett and Feder, 1981; Orensanz et al., 2007). This latitudinal cline in size is most likely a reflection of the impact of conditions that vary with latitude such as bottom water temperature, primary productivity distribution or current regime (Stoker, 1981). Bottom water temperatures in the Chukchi Sea do not just vary with latitude but also with the prevailing currents. The ACC had an average bottom water temperature of $2.55{ }^{\circ} \mathrm{C}$ during the sampled summer month from 2009 to 2013, while the BSW flowing through the Central Channel had an average of $-0.04^{\circ} \mathrm{C}$ and the BSW flowing around Hanna Shoal had average of $-1.62{ }^{\circ} \mathrm{C}$ (Groß, 2015). Bottom water temperatures have been assumed to play a substantial role in the latitudinal cline, as temperature affects growth and hence body size of organisms (MacDonald and Thompson, 1985; McCormick and Molony, 1995). Cold temperatures may be the greatest limitation on $C$. opilio population productivity, as it decreases growth, size-at-maturity, clutch size and slows egg development (Bryant, 1991; Burmeister and Sainte-Marie, 2010; Kolts et al., 2015; Orensanz et al., 2007). Observations of $C$. opilio from west Greenland have shown that the mean CW at instar is similar or larger in colder areas than warmer areas, showing that the relative moult increment is generally invariable (Burmeister and Sainte-Marie, 2010). This is true for $C$. opilio as it is a cold-water species that is not commonly found at temperatures above $5{ }^{\circ} \mathrm{C}$ (Foyle et al., 1989). Differences in size-at-maturity may be due to differences in the intermoult period. Immature crabs can moult more frequently in warmer than colder environments, before the onset of pre-puberty, when the moulting cycle becomes annual (Burmeister and Sainte-Marie, 2010). A north-south variation in the intermoult period was found in the Gulf of St. Lawrence and the Sea of Japan (Comeau et al., 1998; Kon, 1980).

Movement patterns of $C$. opilio in the Chukchi and Beaufort Seas are not well known but the finding of large mature crabs in the Beaufort Sea suggests that conditions varying with latitude might not be the only factors influencing the distribution of this species (Logerwell et al., 2011; Rand and Logerwell, 2011). The study from the Beaufort Sea is the first breaking the pattern of a well-documented latitudinal cline of size-at-maturity being reduced at higher latitudes, with mature $C$. opilio only reaching a size of 40-94 $\mathrm{mm}$ in the Chukchi Sea (Burmeister and Sainte-Marie, 2010; Rand and Logerwell, 2011; Somerton, 1981). Migrations of adolescent and mature crabs could play a role in explaining this unconventional finding of large $C$. opilio in the Beaufort Sea, and the observed latitudinal cline in this study. Ontogenetic migrations tend to follow an "upstream" pattern regarding local currents (Ernst et al., 2005). This seems contrary to the observed pattern as larger crabs were found in the southern regions of the study area; however, large $C$. opilio have also been found in the Beaufort Sea, and southwestward migrations of females were also observed in the Bering Sea (Ernst et al., 2005; Rand and Logerwell, 2011). Since females track environmental gradients along their migrations, especially temperature, movement to warmer areas likely increases their reproductive input to the population (Burmeister and Sainte-Marie, 2010; Ernst et al., 2005). The area in the Beaufort Sea where large individuals of $C$. opilio were found has warmer bottom water temperatures associated with the Atlantic Layer, which likely contributes to the enhanced crab growth (Burmeister and Sainte-Marie, 2010; Orensanz et al., 2007; Pickart et al., 2005). It can be suggested that adolescent and mature C. opilio might migrate to warmer areas in the Chukchi Sea, which could explain why smaller individuals were found further north of Hanna Shoal. The constant cold pool of winter water around Hanna Shoal leads to lower average temperatures compared to the southern part of the study region or the deeper areas in the Beaufort Sea (Pickart et al., 2005; Weingartner et al., 2005). Both, a migration of adolescent and mature crabs to the southern regions of the study area as well as an "upstream" migration with the northeastward flowing currents to the Beaufort Sea are possible explanations for the observed latitudinal cline in body size in the Chukchi Sea.

A second spatial trend was observed in this study with a peak in mean size in region 2 for all but $C$. opilio females, and a minimum in region 4 for both sexes of $H$. coarctatus. Region 2 included the coastal stations, while region 4 included the furthest offshore stations, indicating an inshore-offshore trend in the distribution of both sexes of $H$. coarctatus. Water masses may also provide insights in the longitudinal pattern observed, as it is thought that crabs might track water masses in the Chukchi Sea (Ravelo et al., 2014). The largest mean size of $C$. opilio males and both sexes of $H$. coarctatus were found close to the shore under the warmer ACC water while the smallest mean size of both sexes of $H$. coarctatus were found offshore under colder Bering Sea Water in the Central Channel. It could be that the larger mean size was found close to the coast because crabs show seasonal migrations to shallower waters in the spring for reproduction (Comeau et al., 1991). The warmer waters of the ACC could attract mature crabs undergoing ontogenetic migrations, and foster enhanced growth (Lovrich et al., 1995; Orensanz et al., 2007). However, this trend of larger mean sizes close to the coast was not observed for female $C$. opilio, which stay longer in shallower areas than the males (Conan et al., 1996). In addition, findings from the Gulf of St. Lawrence demonstrated that female adult size followed a longitudinal cline that correlated with increasing temperature (Sainte-Marie and Gilbert, 1998). These seasonal migrations into coastal waters have not yet been observed in the eastern Bering Sea (Ernst et al., 2005). Another explanation for the occurrence of larger crabs in region 2 could be the greater influence of water dynamics through storms and disturbances from ice gouging close to the coast, which co-vary with the shallower water depth and are better tolerated by mature, larger crabs, especially the males, as they are highly mobile and can travel several miles within a few days to avoid big disturbance events (Blanchard and Knowlton, 2013; Kon, 1980; Lovrich et al., 1995).

\subsection{Relationship of SFD with environmental drivers}

The environmental analysis only partially supported the final hypothesis, that the variation in the size frequency distribution would be significantly explained by changing environmental parameters (Tables 5 and 6). Bottom water temperature was not consistently structuring the SFD of $C$. opilio and $H$. coarctatus, and neither were indicators of regional productivity (sediment TOC, $\mathrm{C} / \mathrm{N}$ ratio, and chlorophyll $a$ content). This suggests that temperature itself and indicators of regional productivity are not important in structuring the SFD of crabs in the Chukchi Sea even though higher abundances of epifaunal and infaunal organisms have been correlated with low $\mathrm{C} / \mathrm{N}$ ratios (high quality primary production) around Hanna Shoal and Barrow Canyon (Grebmeier and McRoy, 1989; Ravelo et al., 2014; Schonberg et al., 2014). These results are similar to findings from west Greenland where food supply did not structure the observed cline in $C$. opilio adult size (Burmeister and Sainte-Marie, 2010), even though reduced growth would be expected with less food quality or quantity (Atkinson and Sibly, 1997). Food limitation could lead to a lengthening in the intermoult period, resulting in a smaller size at instar (Burmeister and Sainte-Marie, 2010; Hartnoll, 2001). This does not seem to be the case in the Chukchi Sea, showing that food quality and quantity are not solely structuring the SFD of these crabs. It could be that water masses are the driving factor of crab size distribution patterns in the Chukchi $\mathrm{Sea}$, as temperature, sediment granulometry, $\mathrm{C} / \mathrm{N}$ ratios and salinity differ between water masses (Schaff et al., 1992; Thomsen et al., 1995).

\subsection{Growth and mortality}

Applying the modeled age from the study by Comeau et al. (1998) to 
this data set showed that growth appeared to be constant for all the sampled crabs. This is very similar to the results by Comeau et al. (1998) for C. opilio females, which showed a constant increase in the percent growth increment. However, growth of male $C$. opilio was not constant in other studies, which showed a larger increase of percent carapace width per molt during the immature phase and a further decline in growth after the molt to maturity (Comeau et al., 1998; Watson, 1969). Both these studies showed that growth in each phase (immature, adolescent and mature phase) was constant but that it changed between the phases. For $H$. coarctatus females, constant growth across the different life cycle stages was found in this and one other study (Bryant, 1991). In contrast to results of constant growth in this study, growth of $H$. coarctatus males has been found to be similar to that of $C$. opilio males discussed above (Bryant 1991). There, growth could be broken down into three phases, immature, adolescent, and mature, with a relative decrease of the molt increments between each phase (Bryant, 1991). The decrease in molt increment from the immature phase to the adolescent phase at the puberty molt is assumed to be caused by an early investment into reproductive organs (Bryant, 1991). While both $C$. opilio and $H$. coarctatus females exhibit gonad development before the puberty molt, the testes of $H$. coarctatus males only mature after the puberty molt (Bryant, 1991; Watson, 1970). This does not fully support the findings of this or other studies (Bryant, 1991; Comeau et al., 1998). The constant growth of females of both species would indicate that no energy is diverted from somatic growth to gonad production at the puberty molt. A changing energy investment would only hold true for $C$. opilio males in the studies that show growth decreasing after the puberty molt (Comeau et al. 1998; Watson, 1969). Constant growth in females of both species could be interpreted as a tactic for maximizing body size to the terminal molt, as larger females are more fertile because they are able to produce more eggs (Bryant, 1991).

Mortality of male and female crabs of both species was highest in the latter two study years, and increased with age as assessed by size. This result supports the previously discussed drop in abundance and average maximum size of the $10 \%$ largest individuals of all mature crabs in 2012 and 2013. Comparisons of $H$. coarctatus mortality to other studies were not made, as there are no other ones. However, mortality of male and female $C$. opilio in 2013 was higher (1.65 and 1.53 per year, respectively) compared to other studies. A trawl and commercial catch study showed that mortality was lowest for immature male crabs with 0.136 per year, and highest for mature males of $80-90 \mathrm{~mm} \mathrm{CW}$ with 0.701 per year (Zheng, 2003). Zheng (2003) also showed that a scenario of constant mortality was the most parsimonious model tested. Constant mortality seems more plausible as direct fishing mortality rates for small $C$. opilio males were very small or close to zero in the eastern Bering Sea $C$. opilio fishery. The natural mortality rate of sublegal mature C. opilio males in the northwestern Gulf of St. Lawrence, Canada, derived from a model, was 0.53-1.02 per year while it was 0.66 per year for C. opilio females (Drouineau et al., 2013; Wade et al., 2003). Those mortality estimates are in the same range as the estimates from this study in 2010, the year with the lowest mortality. However, mortality was much higher in this study in 2012 and 2013, indicating that the near absence of adolescent and mature crabs may be caused by increased mortality. Nevertheless, it remains unknown if the near absence of adolescent and mature crabs is caused by increased mortality in the latter study years or the previously mentioned migrations out of the study area. Besides the prominent causes for natural mortality, such as predation and diseases, mortality of mature females could be higher than that of immature females due to densitydependent sexual conflicts arising during the female's mating period (Sainte-Marie et al., 2008). If the adult C. opilio sex ratio is biased towards males, as in this study, dominant males may forcefully take over females from other males, inflicting immediate death or severe injuries that may shorten female life expectancy (Sainte-Marie et al., 2008).

\section{Conclusions}

Interannual fluctuations like the ones observed here through the absence of adolescent and mature crabs of both species in 2012 and 2013 in the northeastern Chukchi Sea, have previously been reported and only future monitoring will show if this is short-term variability or the start of a long-term trend. However, interannual fluctuations have been reported for $C$. opilio populations in other areas, and successful waves of recruitment were estimated to occur in seven or eight year intervals (Ernst et al., 2012; NPFMC, 2010; Sainte-Marie et al., 1995; Zheng et al., 2001). It is still uncertain if these fluctuations are cyclic or instable but they are thought to be an advantage to reduce consumption by predators, which may not specialize on a species that is not readily available every year (Bailey and Elner, 1989; Conan et al., 1992, 1996). It is important to study the SFD of $C$. opilio and $H$. coarctatus because the distribution and growth of both species partly depends on bottom water temperatures and available food sources in the benthic community (Alvsvåg et al., 2009; Comeau et al., 1999; Kon, 1980; Orensanz et al., 2007; Parada et al., 2010; Powell, this issue). As these factors are likely to change in the Arctic, it is important to study the SFD of C. opilio and $H$. coarctatus further to be able to discern if the near absence of adolescent and mature crabs is caused by ontogenetic migrations, interannual fluctuations or if it is an early indication of a further northward extension, a shift in the southern distribution limit, or a regime shift in the Chukchi Sea (Dionne et al., 2003; Orensanz et al., 2004). It would be valuable in the future to study the size at which $C$. opilio and $H$. coarctatus reach maturity in the Chukchi Sea, to see how changing environmental parameters may alter the size at maturity of both species. A logistic regression approach to assess the influence of environmental parameters on size at maturity would have tied in well with the objectives of this study but this specific analysis was left out of the manuscript as the maturity status of sampled crabs was not recorded in the field. Findings from this study are not only of ecological importance but they also have implications for future Arctic C. opilio fisheries. The small number of mature male crabs sampled that reached the legal fishing size ( $>78 \mathrm{~mm}$ ) of the current eastern Bering Sea $C$. opilio fishery shows that a $C$. opilio fishery is currently not viable in the Chukchi Sea.

\section{Acknowledgments}

The U.S. Department of the Interior, Bureau of Ocean Energy Management (BOEM Cooperative Agreement Number M11AC00007 and Contract Number UTA11-000873) provided funding for this study as part of the Chukchi Sea Offshore Monitoring in Drilling Area (COMIDA): Hanna Shoal Ecosystem Project and the BOEM Alaska Environmental Studies Program. From BOEM, we thank Heather Crowley for her continued support of this project and enthusiastic assistance during our cruises. We thank the Fulbright Commission who supported Jasmin Groß during this study. Environmental data were collected by Lee Cooper, Jackie Grebmeier, and John Trefry. We thank Tom Weingartner for sharing his expertise of Chukchi Sea oceanography, David Verbyla for his help with ArcGIS, Bob Clark for all his statistical help with PRIMER, and Katrin Iken, Lauren Bell, Alyssa Lind, Kimberley Powell, Alexandra Ravelo, Tanja Schollmeier and Carlos Serratos for their valuable comments on this manuscript. We thank the captains and crew of the $\mathrm{R} / \mathrm{V}$ Alpha Helix, R/V Moana Wave and USCGC Healy for their dedication and effort at sea. Lastly, we thank all our field assistants and the rest of the COMIDA team for making this such a great group with which to work.

\section{References}

Alunno-Bruscia, M., Sainte-Marie, B., 1998. Abdomen allometry, ovary development, and growth of female snow crab, Chionoecetes opilio (Brachyura, Majidae), in the northwestern Gulf of St. Lawrence. Can. J. Fish. Aquat. Sci. 55 (2), 459-477. 
Alvsvåg, J., Agnalt, A.-L., Jørstad, K.E., 2009. Evidence for a permanent establishment of the snow crab (Chionoecetes opilio) in the Barents Sea. Biol. Invasions 11, 587-595. http://dx.doi.org/10.1007/s10530-008-9273-7.

Atkinson, D., Sibly, R.M., 1997. Why are organisms usually bigger in colder environments? Making sense of a life history puzzle. Trends Ecol. Evol. 12, 235-239.

Bailey, R.F.J., Elner, R.W., 1989. Northwest Atlantic snow crab fisheries: lessons in research and management. In: Caddy, J.F., Wiley, J.\& S. (Eds.), Marine Invertebrate Fisheries: Their Assessment and Management of Shellfish Resources. New York, NY, pp. 261-280.

Blanchard, A.L., Knowlton, A.L., 2013. Chukchi Sea Environmental Studies Program: Benthic Ecology of the Northeastern Chukchi Sea, 2008-2013. Fairbanks, AK.

Bluhm, B.A., Iken, K., Mincks Hardy, S., Sirenko, B.I., Holladay, B.A., 2009. Community structure of epibenthic megafauna in the Chukchi Sea. Aquat. Biol. 7, 269-293. http://dx.doi.org/10.3354/ab00198.

Brey, T., 2001. Population dynamisc in benthic invertebrates. A virtual handbook. Version 01.2. . 〈http://www.thomas-brey.de/science/virtualhandbook〉 (accessed 18.04.15).

Bryant, A.D., 1991. The life history patterns of brachyuran crabs. University of Liverpool.

Brylawski, B.J., Miller, T.J., 2006. Temperature-dependent growth of the blue crab (Callinectes sapidus): a molt process approach. Can. J. Fish. Aquat. Sci. 63, 1298-1308. http://dx.doi.org/10.1139/f06-011.

Burmeister, A., 2002. Preliminary notes on the reproduction conditions of mature female snow crab (Chionoecetes opilio) from Disko Bay and Sisimiut, West Greenland. In: Paul, A.J., Dawe, E.G., Elner, R., Jamieson, G.S., Kruse, G.H., Otto, R.S., Sainte-Marie, B., Shirley, T.C., Woodby, D. (Eds.), Crab 2001: Crabs in Cold Water Regions: Biology, Management and Economics. University of Alaska Sea Grant.

Burmeister, A., Sainte-Marie, B., 2010. Pattern and causes of a temperature-dependent gradient of size at terminal moult in snow crab (Chionoecetes opilio) along West Greenland. Polar Biol. 33, 775-788. http://dx.doi.org/10.1007/s00300-009-0755-6.

Calder, W.A., 1984. Size, function, and life history. Harvard University Press, Cambridge, Mass.

Comeau, M., Conan, G.Y., Maynou, F., Robichaud, G., Therriault, J.-C., Starr, M., 1998. Growth, spatial distribution, and abundance of benthic stages of the snow crab (Chionoecetes opilio) in Bonne Bay, Newfoundland, Canada. Can. J. Fish. Aquat. Sci. 55, 262-279. http://dx.doi.org/10.1139/cjfas-55-1-262.

Comeau, M., Conan, G.Y., Robichaud, G., Jones, A., 1991. Life history patterns and population fluctuations of snow crab (Chionoecetes opilio) in the fjord of Bonne Bay on the west coast of Newfoundland, Canada, from 1983 to 1990. Can. Tech. Rep. Fish. Aquat. Sci. 1817, 1-73.

Comeau, M., Starr, M., Conan, G.Y., Robichaud, G., Therriault, J.-C., 1999. Fecundity and duration of egg incubation for multiparous female snow crabs (Chionoecetes opilio) in the fjord of Bonne Bay, Newfoundland. Can. J. Fish. Aquat. Sci. 56, 1088-1095.

Company, J.B., Sarda, F., 2000. Growth parameters of deep-water decapod crustaceans in the Northwestern Mediterranean Sea: a comparative approach. Mar. Biol. 136, 79-90. http://dx.doi.org/10.1007/s002270050011.

Conan, G.Y., Comeau, M., Robichaud, G., 1992. Life history and fishery management of majid crabs: the case study of the Bonne Bay (Newfoundland) Chionoecetes opilio population. Int. Counc. Explor (Sea C.M. 1992/K 21, 24 pp).

Conan, G.Y., Starr, M., Comeau, M., Therriault, J.-C., Hernandez, F.X.M., Robichaud, G., 1996. Life History Strategies, Recruitment Fluctuations, and Management of the Bonne Bay Fjord Atlantic Snow Crab (Chionocetes opilio). In: High Latitude Crabs: Biology, Management, and Economics. Alaska Sea Grant College, Anchorage, AK, pp. 59-97.

Dawe, E.G., Colbourne, E.B., 2002. Distribution and Demography of Snow crab (Chionoecetes opilio) males on the Newfoundland and Labrador shelf, in: Paul, A.J., Dawe, E.G., Elner, R., Jamieson, G.S., Kruse, G.H., Otto, R.S., Sainte-Marie, B., Shirley, T.C., Woodby, D. (Eds.), Crabs in Cold Water Regions, Biology, Ma.

Day, R.H., Weingartner, T.J., Hopcroft, R.R., Aerts, L.A.M., Blanchard, A.L., Gall, A.E., Gallaway, B.J., Hannay, D.E., Holladay, B.A., Mathis, J.T., Norcross, B.L., Questel, J.M., Wisdom, S.S., 2013. The offshore northeastern Chukchi Sea, Alaska: a complex high-latitude ecosystem. Cont. Shelf Res. 67, 147-165. http://dx.doi.org/10.1016/j. csr.2013.02.002.

Dionne, M., Sainte-Marie, B., Bourget, E., Gilbert, D., 2003. Distribution and habitat selection of early benthic stages of snow crab Chionoecetes opilio. Mar. Ecol. Prog. Ser. 259, 117-128. http://dx.doi.org/10.3354/meps259117.

Divine, L.M., Bluhm, B.A., Mueter, F.J., Iken, K., 2015. Diet analysis of Alaska Arctic snow crabs (Chionoecetes opilio) using stomach contents and $813 \mathrm{C}$ and $815 \mathrm{~N}$ stable isotopes. Deep Sea Res. II.

Drouineau, H., Sainte-Marie, B., Duplisea, D., 2013. Estimating natural mortality and egg production of snow crab Chionoecetes opilio adult females. Aquat. Biol. 18, 261-270. http://dx.doi.org/10.3354/ab00513.

Dunton, K.H., Prentki, D., Harvey, R., Lanoux, S., Konar, B., Schonberg, S.V., Grebmeier, J.M., Cooper, L.W., Trefry, J.H., 2015.Chukchi Sea Offshore Monitoring in Drilling Area (Chemical and Benthos) Proj. Webpage. 〈http://arcticstudies.org/comidacab〉 (accessed 7.13.16)

Émond, K., Sainte-Marie, B., Galbraith, P.S., Bêty, J., 2015. Top-down vs. bottom-up drivers of recruitment in a key marine invertebrate: investigating early life stages of snow crab. ICES J. Mar. Sci. 1-13.

Ernst, B., Armstrong, D.A., Burgos, J., Orensanz, J.M. (Lobo), 2012. Life history schedule and periodic recruitment of female snow crab (Chionoecetes opilio) in the eastern Bering Sea. Can. J. Fish. Aquat. Sci. 69, 532-550. http://dx.doi.org/10.1139/f2011 173.

Ernst, B., Orensanz, J.M. (Lobo), Armstrong, D.A., 2005. Spatial dynamics of female snow crab (Chionoecetes opilio) in the eastern Bering Sea. Can. J. Fish. Aquat. Sci. 62, 250-268. http://dx.doi.org/10.1139/F04-201.

Feder, H.M., Jewett, S.C., Blanchard, A.L., 2005. Southeastern Chukchi Sea (Alaska) epibenthos. Polar Biol. 28, 402-421. http://dx.doi.org/10.1007/s00300-004-0683-4. Foyle, T.P., O'Dor, R.K., Elner, R.W., 1989. Energetically Defining the Thermal Limits of the Snow Crab. J. Exp. Biol. 145, 371-393.

Frost, K.J., Lowry, L.F., 1983. Demersal fishes and invertebrates trawled in the northeastern Chukchi and western Beaufort Seas, 1976-77.

Goodman, S.E., June, J.A., Antonelis, K.L., 2012. 2011 Fish and Invertebrate Trawl Surveys in the Chukchi Sea Environmental Studies Program.

Grebmeier, J.M., 2012. Shifting patterns of life in the pacific arctic and sub-arctic seas. Ann. Rev. Mar. Sci. 4, 63-78. http://dx.doi.org/10.1146/annurev-marine-120710100926.

Grebmeier, J.M., Bluhm, B.A., Cooper, L.W., Danielson, S., Arrigo, K.R., Blanchard, A.L., Clark, J.T., Day, R.H., Frey, K.E., Gradinger, R.R., Kedra, M., Konar, B., Kuletz, K.J., Lee, S.H., Lovvorn, J.R., Norcross, B.L., Okkonen, S.R., 2015b. Ecosystem characteristics and processes facilitating persistent macrobenthic biomass hotspots and associated benthivory in the Pacific Arctic. Prog. Oceanogr. 136, 92-114.

Grebmeier, J.M., McRoy, C.P., 1989. Pelagic-benthic coupling on the shelf of the northern Bering and Chukchi Seas. III. Benthic food supply and carbon cycling. Mar. Ecol. Prog. Ser. 53, 79-91.

Groß, J., 2015. Variability in the Size Frequency Distribution and Growth of Snow Crab (Chionoecetes opilio) and Lyre Crab (Hyas coarctatus) in the Chukchi Sea from 2009 to 2013. University of Bremen, Bremen, Germany.

Hardy, S.M., Lindgren, M., Konakanchi, H., Huettmann, F., 2011. Predicting the Distribution and Ecological Niche of Unexploited Snow Crab (Chionoecetes opilio) Populations in Alaskan Waters: a First Open-Access Ensemble Model. Integr. Comp. Biol. 51, 608-622. http://dx.doi.org/10.1093/icb/icr102.

Hartnoll, R.G., 1982. Growth. In: Abele, L.G. (Ed.), The Biology of the Crustacea. Academic Press, New York, NY, pp. 111-196.

Hartnoll, R.G., 2001. Growth in Crustacea-20 years on. Hydrobiologia 449, 111-122.

Hines, A.H., 1982. Allometric constraints and variables of reproductive effort in brachyuran crabs. Mar. Biol. 69, 309-320.

Jadamec, L.S., Donaldson, W.E., Cullenberg, P., 1999. Biological field techniques for Chionoecetes crabs. University of Alaska Sea Grant College Program, Fairbanks, AK.

Jewett, S.C., Feder, H.M., 1981. Epifaunal invertebrates of the continental shelf of the eastern Bering and Chukchi Seas. In: Hood, D.W., Calder, J.A. (Eds.), The Eastern Bering Sea Shelf: Oceanography and Resources 2 U S Department of Commerce, NOAA, Rockville, Maryland.

Kolts, J., Lovvorn, J.R., North, C.A., Janout, M.A., 2015. Oceanographic and demographic mechanisms affecting population structure of snow crabs in the northern Bering Sea. Mar. Ecol. Prog. Ser. 518, 193-208. http://dx.doi.org/10.3354/meps11042.

Kolts, J.M., Lovvorn, J.R., North, C.A., Grebmeier, J.M., Cooper, L.W., 2013. Effects of body size, gender, and prey availability on diets of snow crabs in the northern Bering Sea. Mar. Ecol. Prog. Ser. 483, 209-220. http://dx.doi.org/10.3354/meps10292.

Kon, T., 1980. Studies on the life history of the Zuwai crab, Chionoecetes opilio (O. Fabricius). Spec. Publ. from Sado Mar. Biol. Station. Niigata Univ. 2.

Konar, B., Ravelo, A.M., Grebmeier, J.M., Trefry, J.H., 2014. Size frequency distributions of key epibenthic organisms in the eastern Chukchi Sea and their correlations with environmental parameters. Deep Sea Res. Part II Top. Stud. Oceanogr. 102, 107-118.

Lanteigne, C., Beninger, P.G., Gionet, C., 1996. Ontogeny of female primary sexual characters in the majid crabs Chionoecetes opilio and Hyas coarctatus. J. Crustac. Biol. $16,501-514$.

Lefebvre, L., Brêthes, J.-C.F., 1991. Influence de la croissance et de facteurs du milieu sur l'alimentation du crabe des neiges, Chionoecetes opilio (O. Fabricius), dans le sudouest du golfe du Saint-Laurent. Can. J. Zool. 69, 489-494.

Logerwell, E.A., Rand, K., Weingartner, T.J., 2011. Oceanographic characteristics of the habitat of benthic fish and invertebrates in the Beaufort Sea. Polar Biol. 34, 1783-1796.

Lovrich, G.A., Sainte-Marie, B., Smith, B.D., 1995. Depth distribution and seasonal movements of Chionoecetes opilio (Brachyura: majidae) in Baie Sainte-Marguerite, Gulf of Saint Lawrence. Can. J. Zool. 73, 1712-1726.

MacDonald, B., Thompson, R.J., 1985. Influence of temperature and food availability on the ecological energetics of the giant scallop Placopecten magellanicus. I. Growth rates of shell and somatic tissue. Mar. Ecol. Prog. Ser. 25, 279-294.

MacGinitie, G.E., 1955. Distribution and ecology of marine invertebrates of Point Barrow. Alasak. Smithson. Misc. Collect. 128, 201.

McCormick, M.I., Molony, B.W., 1995. Influence of Water Temperature During the Larval Stage on Size, Age and Body Condition of a Tropical Reef Fish at Settlement. Mar Ecol. Ser. 118, 59-68.

National Marine Fisheries Service, 2016. Fisheries of the United States, 2015. U.S. Department of Commerce, NOAA Current Fishery Statistics No. 2015. 〈www.st.nmfs noaa.gov/commercial-fisheries/fus/fus15/index $\rangle$ (accessed 30.01.17).

NPFMC, 2010. Stock assessment and fishery evaluation report for the King and Tanner $\mathrm{Crab}$ fisheries of the Bering Sea and Aleutian Islands Regions. Anchorage, AK.

Orensanz, J.M. (Lobo), Ernst, B., Armstrong, D.A., 2007. Variation of female size and stage at maturity in snow crab (Chionoecetes opilio) (Brachyura: majidae) from the Eastern Bering Sea. J. Crustac. Biol. 27, 576-591. http://dx.doi.org/10.1651/S2790.1.

Orensanz, J.M. (Lobo), Ernst, B., Armstrong, D.A., Stabeno, P., Livingston, P., 2004 Contraction of the geographic range of distribution of snow crab (Chionoecetes opilio) in the eastern Bering Sea: an environmental ratchet? Calif. Coop. Ocean. Fish. Investig. Rep. 45, 65-79. http://dx.doi.org/10.1016/j.fishres.2003.09.029.

Parada, C., Armstrong, D.A., Ernst, B., Hinckley, S., Orensanz, J.M. (Lobo), 2010. Spatial Dynamics of Snow Crab (Chionoecetes opilio) in the Eastern Bering Sea-Putting Together the Pieces of the Puzzle. Bull. Mar. Sci. 86, 413-437.

Pickart, R.S., Weingartner, T.J., Pratt, L.J., Zimmermann, S., Torres, D.J., 2005. Flow of winter-transformed Pacific water into the Western Arctic. Deep. Res. Part II Top. Stud. Oceanogr. 52, 3175-3198. 
Piepenburg, D., 2005. Recent research on Arctic benthos: common notions need to be revised. Polar Biol. 28, 733-755.

Piepenburg, D., Ambrose, W.G.J., Brandt, A., Renaud, P.E., Ahrens, M.J., Jensen, P., 1997. Benthic community patterns reflect water column processes in the Northeast Water polynya (Greenland). J. Mar. Syst. 10, 467-482.

Powell, K., 2015. Interannual Variation of Epibenthic Communities in the Chukchi Sea, Alaska. University of Alaska Fairbanks, Fairbanks, AK (this issue).

Puebla, O., Sévigny, J.-M., Sainte-Marie, B., Brêthes, J.-C.F., Burmeister, A., Dawe, E.G., Moriyasu, M., 2008. Population genetic structure of the snow crab (Chionoecetes opilio) at the Northwest Atlantic scale. Can. J. Fish. Aquat. Sci. 65, 425-436. http:// dx.doi.org/10.1139/f07-163.

Rand, K.M., Logerwell, E.A., 2011. The first demersal trawl survey of benthic fish and invertebrates in the Beaufort Sea since the late 1970s. Polar Biol. 34, 475-488. http://dx.doi.org/10.1007/s00300-010-0900-2.

Ravelo, A.M., Konar, B., Trefry, J.H., Grebmeier, J.M., 2014. Epibenthic community variability in the northeastern Chukchi Sea. Deep Sea Res. Part II Top. Stud. Oceanogr. 102, 119-131. http://dx.doi.org/10.1016/j.dsr2.2013.07.017.

Robichaud, D.A., Bailey, R.F.J., Elner, R.W., 1989. Growth and distribution of snow crab, Chionoecetes opilio, in the southern Gulf of St. Lawrence. J. Shellfish Res. 8, 13-23.

Sainte-Marie, B., Gilbert, D., 1998. Possible effects of change in CIL temperature and thickness on population dynamics of snow crab, Chionoecetes opilio, in the Gulf of Saint Lawrence. Can. Stock Assess. Secr. Res. Doc. 98, 19.

Sainte-Marie, B., Gosselin, T., Sévigny, J.-M., Urbani, N., 2008. The snow crab mating system: opportunity for natural and unnatural selection in a changing environment. : Bull. Mar. Sci. 131-161.

Sainte-Marie, B., Raymond, S., Brêthes, J.-C.F., 1995. Growth and maturation of the benthic stages of male snow crab, Chionoecetes opilio (Brachyura: majidae). Can. J. Fish. Aquat. Sci 52, 903-924.

Schaff, T., Levin, L., Blair, N., DeMaster, D., Pope, R., Boehme, S., 1992. Spatial heterogeneity of benthos on the Carolina continental slope: large (100 km)-scale variation. Mar. Ecol. Prog. Ser. 88, 143-160.

Schonberg, S.V., Clarke, J.T., Dunton, K.H., 2014. Distribution, abundance, biomass and diversity of benthic infauna in the Northeast Chukchi Sea, Alaska: relation to environmental variables and marine mammals. Deep. Res. Part II Top. Stud. Oceanogr. 102. pp. 144-163. http://dx.doi.org/10.1016/j.dsr2.2013.11.004.

Somerton, D.A., 1981. Life history and population dynamics of two species of Tanner crab, Chionoecetes bairdi and C. opilio, in the eastern Bering Sea with implications for the management of the commercial harvest. University of Washington, Seattle.
Stoker, S., 1981. Benthic invertebrate macrofauna of the Eastern Bering/Chukchi Continental Shelf. In: Hood, D.W., Calder, J.A. (Eds.), The Eastern Bering Sea Shelf: Oceanography and Resources 2. U S Department of Commerce, NOAA, Rockville, Maryland, pp. 1069-1090.

Teissier, G., 1960. Relative growth. In: Waterman, T.H. (Ed.), The Physiology of Crustacea Vol I. Metabolism and Growth. Academic Press, New York, NY, pp. 537-560.

Thomsen, L., Graf, G., Von Juterzenka, K., Witte, U., 1995. An in situ experiment to investigate the depletion of seston above an interface feeder field on the continental slope of the western Barents Sea. Mar. Ecol. Prog. Ser. 123, 295-300.

Wade, E., Surette, T., Apaloo, J., Moriyasu, M., 2003. Estimation of mean annual natural mortality for adult male snow crab Chionoecetes opilio in the southern Gulf of St. Lawrence.

Watson, J., 1969. Biological investigations on the spider crab. Chionoecetes opilio (Fredericton).

Watson, J., 1970. Maturity, mating, and egg laying in the spider crab, Chionoecetes opilio. J. Fish. Res. Board Can. 27, 1607-1616.

Weingartner, T.J., Aagaard, K., Woodgate, R.A., Danielson, S., Sasaki, Y., Cavalieri, D., 2005. Circulation on the north central Chukchi Sea shelf. Deep Sea Res. Part II Top. Stud. Oceanogr. 52, 3150-3174. http://dx.doi.org/10.1016/j.dsr2.2005.10.015.

Weingartner, T.J., Dobbins, E., Danielson, S., Winsor, P., Potter, R., Statscewich, H., 2013. Hydrographic variability over the northeastern Chukchi Sea shelf in summer-fall 2008-2010. Cont. Shelf Res. 67, 5-22. http://dx.doi.org/10.1016/j.csr.2013.03.012.

Welch, J.M., Epifanio, C.E., 1995. Effect of variations in prey abundance on growth and development of crab larvae reared in the laboratory and in large field-deployed enclosures. Mar. Ecol. Prog. Ser. 116, 55-64.

Wieczorek, S.K., Hooper, R.G., 1995a. Relationship between diet and food availability in the snow crab Chionoecetes opilio (O-Fabricius) in Bonne Bay, Newfoundland. J. Crustac. Biol. 15, 236-247.

Wieczorek, S.K., Hooper, R.G., 1995b. Relationship between Diet and Food Availability in the Snow Crab Chionoecetes opilio (O. Fabricius) in Bonne Bay, Newfoundland. J. Crustac. Biol. 15, 236-247.

Zheng, J., 2003. Uncertainties of natural mortality estimates for eastern Bering Sea snow crab, Chionoecetes opilio. Calif. Coop. Ocean. Fish. Investig. Rep. 65, 411-425. http:// dx.doi.org/10.1016/j.fishres.2003.09.029.

Zheng, J., Kruse, G.H., Ackley, D.R., 2001. Spatial distribution and recruitment patterns of snow crabs in the eastern Bering Sea. In Spatial processes and management of marine populations. Fairbanks, AK. 